\title{
Da cor à imagem urbana: paradigmas contemporâneos nas cores do patrimônio cultural brasileiro'
}

From color to urban image: Contemporary paradigms in the colors of Brazilian cultural heritage

hitps://doi.org/10.1590/1982-02672021v29e55

\section{LUCIANA DA SILVA FLORENZANO²}

https://orcid.org/0000-0002-8235-7104

Universidade Federal do Rio de Janeiro / Rio de Janeiro, RJ, Brasil

\section{ROSINA TREVISAN MARTINS RIBEIRO ${ }^{3}$}

https: / / orcid.org/0000-000 1-5578-7419

Universidade Federal do Rio de Janeiro / Rio de Janeiro, RJ, Brasil

RESUMO: A segunda metade do século XX foi marcada pela revisão e crítica à ideologia do movimento moderno e por novas abordagens dos conceitos de cultura e de história, cujas reverberações estenderam-se aos bens culturais. $\bigcirc$ objeto do patrimônio começou a abranger novas temporalidades e naturezas de valor patrimonial e passou a ser aplicado a tipologias materiais e imateriais, momento em que produz uma mercadoria e um objeto de consumo. Inseridas nesse contexto, as cores das superfícies arquitetônicas refletem as práticas de preservação e os princípios gerais que norteiam as intervenções. Nesse cenário, este artigo enfatiza as narrativas imagéticas e identifica a recorrência de atitudes estruturantes na base das intervenções cromáticas em bens culturais edificados. Identificadas como paradigmas, fundamentam-se no culto ao valor de novidade, em tendências cromáticas como o uso do amarelo na arquitetura historicista e no turismo cultural. $\bigcirc$ artigo analisa a existência de tais paradigmas a partir de intervenções cromáticas realizadas em bens culturais edificados no Brasil. O referencial teórico aborda o conceito de imagem urbana e é fundamentado nas

\begin{abstract}
1. O presente trabalho foi realizado com apoio da Coordenação de Aperfeiçoamento de Pessoal de Nível Superior (CAPES); Código de Financiamento 001.

2. Arquiteta e Urbanista pela Universidade Federal do Pará (UFPA). Mestre em Arquitetura e Urbanismo pela Universidade Federal do Espírito Santo (UFES). Doutoranda em Arquitetura na Universidade Federal do Rio de Janeiro (UFRJ) pelo Programa de Pós-graduação em Arquitetura (Proarq). E-mail: <lucianaflorenzano@gmail. com>.
\end{abstract}

3. Atualmente é Professora do quadro Permanente do Programa de Pós-graduação em Arquitetura (Proarq) da Universidade Federal do Rio de Janeiro (UFRJ) e do Mestrado Profissional em Projeto e Patrimônio do Proarq/UFRJ. E-mail: <rosinatrevisan@gmail.com>. 
reflexões de Jean Baudrillard, Guy Debord, Pierre Jeudy, no restauro crítico de Cesare Brandi e na interpretação cultural contemporânea de Flávio Carsalade. Os resultados demonstram que apesar do discurso teórico consolidado que preconiza a análise caso a caso, na prática as decisões projetuais cromáticas não refletem as tendências atuais da teoria da restauração e revelam que a questão da cor no patrimônio cultural não foi superada e deve ser discutida em toda sua complexidade histórica, teórica e fenomenológica.

PALAVRAS-CHAVE: Intervenções cromáticas. Cor. Imagem urbana. Patrimônio cultural. Paradigmas.

ABSTRACT: The second half of the 20th century was marked by the revision and critique to the modern movement ideology and by new approaches to culture and history, whose reverberations extended to cultural goods. With that, the notion of cultural heritage expands and incorporates material and immaterial typologies, producing a commodity and an object of consumption. In this context, the colors of architectural surfaces reflect the preservation practices and general principles guiding the interventions. This article emphasizes the narratives of urban images and identifies the recurrence of certain paradigms - which express the value of novelty within a chromatic trend, such as the use of yellow in historicist architecture and the cultural tourism - on the basis of chromatic interventions conducted in Brazilian historic buildings. The theoretical framework consists of the reflections of Jean Baudrillard, Guy Debord, and Pierre Jeudy; the critical restoration of Cesare Brandi; and the cultural interpretation of Flávio Carsalade. Results indicate that, although the consolidated theory recommends a case-by-case analysis, in practice, design decisions are not supported by current trends in restoration theory, besides revealing that the issue of chromatic interventions in cultural heritage has not been overcome and should be discussed in its historical, theoretical, and phenomenological complexity.

KEYWORDS: Chromatic interventions. Color. Urban image. Cultural heritage. Paradigms. 
INTRODUÇÃO

Ao falar de cores na arquitetura, uma das primeiras questões que emergem é, certamente, sua intrínseca relação com a composição formal, especialmente no processo de projeto em ambientes internos. Mas as cores não proporcionam apenas aproximações perceptivas entre o homem e seus espaços habitáveis. A cor é elemento determinante para a produção urbana, cuja complexidade cria imagens e discursos que dialogam com determinada situação cultural. Consequentemente, estudar as cores das superfícies arquitetônicas é estudar tanto os processos formais compositivos da arquitetura quanto os processos estruturantes do meio urbano, na medida em que as cores são essenciais à orientação humana e à própria leitura da arquitetura. $\bigcirc$ aspecto urbano das cores das superfícies arquitetônicas tem sido estudado no âmbito das cidades históricas desde a década de 1970 na Europa, quando iniciativas pioneiras trabalharam com alternativas a partir de planos de cor. ${ }^{4}$ Significativos estudos cromáticos foram realizados por Lancaster ${ }^{5}$ em sua publicação Colourscape e por Lenclos e Lenclos, ${ }^{6}$ cujo livro intitulado Colors of the World, abrange análises de cidades brasileiras como Salvador e Cachoeira, na Bahia.

No campo do patrimônio cultural, no período em questão, ocorreram importantes avanços na ciência da conservação quanto à caracterização físico, química e mineralógica de diversos materiais, o que viabilizou constatações sobre datações de camadas de cor nas estratigrafias murais das fachadas. No âmbito teórico, as cores também foram objeto de análise dos profissionais envolvidos com a preservação do patrimônio cultural e pode-se dizer que há um consenso entre diversas correntes teóricas ocidentais que argumentam sobre a necessidade de se analisar cada intervenção cromática para além de seus aspectos técnicos. Trata-se de um posicionamento em conformidade com os princípios teóricos do restauro crítico, cujo principal expoente foi o italiano Cesare Brandi, autor do livro Teoria da restauração, publicado originalmente em 1963. Nessa publicação, embora Brandi ${ }^{7}$ não discorra diretamente sobre a cor das superfícies arquitetônicas, em vários momentos aborda a problemática da pátina, isto é, o efeito da passagem do tempo sobre as superfícies externas de bens móveis e imóveis. Para ele, na medida em que a pátina é um fenômeno intrínseco ao tempo decorrido a partir da criação da obra de arte, sua conservação é um modo de manter os testemunhos históricos e, portanto, seria equivocado contradizer a própria antiguidade da obra alterando a matéria para simular um frescor de novidade.

Em outra publicação, Brandi ${ }^{8}$ reforça que o problema das cores na arquitetura não pode se esgotar na enunciação de alguns princípios básicos, salientando que as intervenções cromáticas podem desequilibrar todo um complexo
4. Uma das possibilidades de renovar a cor com uma pintura tem sido tomada a partir da análise de planos de cor próprios para aquele território, os quais envolvem além de uma intensa discussão teórica, investigação sobre os pigmentos da região, formação de mão de obra qualificada para intervir em materiais antigos, pesquisa histórica, codificação em sistemas de medição cromática, além do necessário envolvimento das comunidades residentes. Cf. Aguiar (2002).

5. Lancaster (1996).

6. Lenclos e Lenclos (2004).

7. Brandi (2008).

8. Id. (2009). 
9. Ibid., p. 59.

10. Carbonara (2006).

11. Ibid.

12. Ibid., Brandi 1894 apud Carbonara, op. cit.

13. Ibid.

14. Ibid., Brandi 1894 apud Carbonara, op. cit., p. 14.

15. Id., 1997.

16. Id., 2020 urbano. Nesse sentido, ele se posiciona com uma visão ainda mais conservativa, pois admite a possibilidade de consolidar camadas antigas, mas nunca com o intuito de retornar às cores originais, intenção que ele descarta e denomina de "historicamente absurda". ${ }^{9}$ Para ele, a busca de uma condição de originalidade alteraria um equilíbrio que vinha sendo consolidado entre edifício e meio urbano e descartaria a passagem do tempo manifestada na obra, além de ser impossível criar um aspecto cromático realmente idêntico ao original das superfícies.

Carbonara ${ }^{10}$ também discorreu a respeito da pátina, afirmando que tanto ela quanto a cor correspondem, sobretudo, a um problema do âmbito da conservação. Isto é, para ele, a conservação demanda a permanência do colorido antigo através da perpetuação da matéria, ainda que não seja original e esteja desbotado. Carbonara ${ }^{11}$ reforça seu posicionamento recorrendo ao pensamento do próprio Brandi, que salienta que a cor na arquitetura histórica deve ser encarada assim como a questão da pátina e dos vernizes em processos de restaurações pictóricas, já que do ponto de vista teórico vigoram os mesmos princípios, apesar de a arquitetura distinguir-se por seu vínculo intrínseco com a cidade. ${ }^{12}$ Nesse ponto, Carbonara ${ }^{13}$ observa que Brandi pondera acerca da preferência da instância estética sobre a histórica e alega que, na arquitetura, a depender do caso, a "identidade histórica poderá ter precedência também sobre a identidade estética". ${ }^{14}$

Carbonara ${ }^{15}$ já havia argumentado, em seu livro Avvicinamento al restauro, que as cores das superfícies arquitetônicas assumem um valor positivo em suas mutações justamente porque sugerem a passagem do tempo, além de ter ressaltado que essa percepção é essencial ao homem. $\bigcirc$ mesmo posicionamento é visto em uma publicação mais recente, em que Carbonara, ${ }^{16}$ ao discorrer sobre restaurações cromáticas que negligenciam a trajetória histórica do patrimônio, reforça que intervenções dessa natureza retiram as estratificações que tenham se consolidado até $\mathrm{o}$ momento. Ademais, o teórico italiano novamente se posiciona contra restaurações arquitetônicas que buscam recuperar as cores "primitivas", salientando que elas têm como base uma pesquisa histórico-filológica, cujos resultados na prática demonstram uma maneira muito simplista de lidar com a questão.

Assim, diante do exposto, pode-se afirmar que as cores das superfícies arquitetônicas precisam ser analisadas no projeto de restauro, em que não se deve buscar um retorno às supostas cores originais. Trata-se de um posicionamento que preconiza que a restauração respeite a história da edificação ao longo do tempo, de modo que um retorno à cor original seja ponderado com cautela, a depender de diversas variáveis, tanto do ponto de vista da investigação histórica quanto da investigação sobre o valor da camada original, caso cubra grandes áreas, em observância também às estratificações que vieram em seguida e ao seu possível 
valor. É, portanto, um trabalho de julgamento crítico, em que se deve avaliar as prospecções pictóricas para que seja tomada a decisão. Essas definições conceituais foram defendidas por importantes teóricos que atuam na preservação do patrimônio cultural, como Brandi17 e Carbonara, ${ }^{18}$ mas também Philippot, ${ }^{19}$ Vitiello ${ }^{20}$ e Aguiar ${ }^{21}$ no âmbito internacional e, no contexto brasileiro, significativos artigos foram publicados por Kühl, ${ }^{22}$ Rosada $^{23}$ e Bezerra e Nappi. ${ }^{24}$

A partir desse contexto teórico inicial, cabe salientar a importância de temas que atravessam a análise deste artigo, ainda que não sejam conteúdos que serão aqui analisados, como a questão da autenticidade. Considerando que esse é um termo complexo que tem sido amplamente discutido, é pertinente destacar que a noção de autenticidade é abordada com diferentes posturas mesmo dentro do Ocidente e seu entendimento varia em cada área, seja a Conservação urbana, o Turismo cultural ou a Teoria e crítica da arte. ${ }^{25}$ Apesar da complexidade da questão, para Lira, ${ }^{26}$ embora essas três áreas tenham diferenças profundas, compartilham o entendimento de que a autenticidade deve ser avaliada a partir de uma perspectiva que contemple tanto sua dimensão material quanto seus aspectos imateriais.

Frente a esse cenário, verifica-se que no panorama teórico prevalece o estabelecimento de que cada caso seja analisado de maneira particular, articulando a materialidade do bem cultural com seus aspectos imateriais por meio das noções de identificação, orientação e valores a ele atribuídos. Ademais, ainda que existam várias vertentes dentro da teoria do restauro, como aquela denominada de "críticoconservativa e criativa", fundamentada na teoria brandiana, ou a vertente chamada de "pura conservação", cuja postura preconiza a instância histórica, ou ainda a "manutenção-repristinação", que salienta uma tendência analógica - todas indicam um respeito pelo valor histórico do bem cultural. ${ }^{27}$ Mesmo as interpretações culturais contemporâneas, como a de Carsalade, ${ }^{28}$ que se apoia em outras vertentes teóricas que defendem a dimensão fenomenológica, salientam que uma experiência verdadeiramente cultural deve ser ancorada no entendimento da obra como um palimpsesto e de maneira a fortalecer valores e não a criar sensações manipuladas.

Dessa forma, ao observar os princípios norteadores tanto de vertentes alinhadas à teoria brandiana quanto de posturas com interpretações culturais mais recentes, verifica-se um discurso que preconiza a irreversibilidade do tempo e a necessidade de processos de identificação entre indivíduo e obra. Coerentes com essas vertentes da teoria, o discurso teórico sobre a preservação cultural brasileira também preconiza a irreversibilidade do tempo e a identidade coletiva, além de demonstrar o conhecimento geral, entre os profissionais que trabalham com a preservação do patrimônio cultural, de que a identidade cromática é um fator essencial à conservação do patrimônio urbano. Apesar dos trabalhos importantes publicados, como os de Kühl, ${ }^{29}$ Rosada $^{30} \mathrm{e}$
17. Brandi (2008, 2009).

18. Carbonara $(1997,2004$, 2006, 2020).

19. Philippot (1966).

20. Vitiello (2011, 2012).

21. Aguiar (2002).

22. Kühl (2004).

23. Rosada (2014).

24. Bezerra e Nappi (2012).

25. Cf. Lira (2009).

26. Ibid.

27. Kühl, op. cit.

28. Carsalade (2014)

29. Kühl, op. cit.

30. Rosada, op. cit. 
31. Bezerra e Nappi, op. cit.

32. Kuhn (1998).

33. Cf. Machado (2012).

Figura 1 - Teatro Municipal do Rio de Janeiro. Fonte: Disponível em: <https://bit. ly/3Amdg7p>. Acesso em: O6 out. 2021.

de Bezerra e Nappi, ${ }^{31}$ não há coerência entre o discurso teórico e a prática da restauração arquitetônica no Brasil quanto ao problema das cores. Na maioria das intervenções de restauro, não se percebe um tratamento cromático voltado para uma interpretação do local em suas múltiplas camadas, pois prevalecem, em contrapartida, situações que revelam padrões de estrutura mental subjacentes às decisões cromáticas em restaurações de bens edificados. De um ponto de vista histórico, esses padrões podem ser denominados do que Kuhn ${ }^{32}$ chamou de paradigmas. Para ele, mais do que um padrão, a palavra paradigma expressa um processo complexo composto por um conjunto de valores compartilhados por uma comunidade que estruturam a realidade a partir do ordenamento de fenômenos, incluindo técnicas, métodos e até teorias.

Um exemplo concreto que ilustra um dos paradigmas identificados nas cores do patrimônio cultural brasileiro é a intervenção realizada no Teatro Municipal do Rio de Janeiro: em sua obra de restauro, ocorrida em 2008, encontrou-se vestígios de um douramento antigo em trechos do domo do telhado, ${ }^{33}$ então, decidiu-se estabelecer por completo um novo douramento de vários elementos da cobertura (Figura 1), por meio de uma pintura dourada com um aspecto de novo e brilhante. Vale observar que, finalizado em 1909, o Teatro Municipal chegou até a contemporaneidade com a pátina característica da passagem do tempo e que o douramento, em seu projeto, não tinha a intensidade daquele realizado na restauração de 2008 (Figura 2).

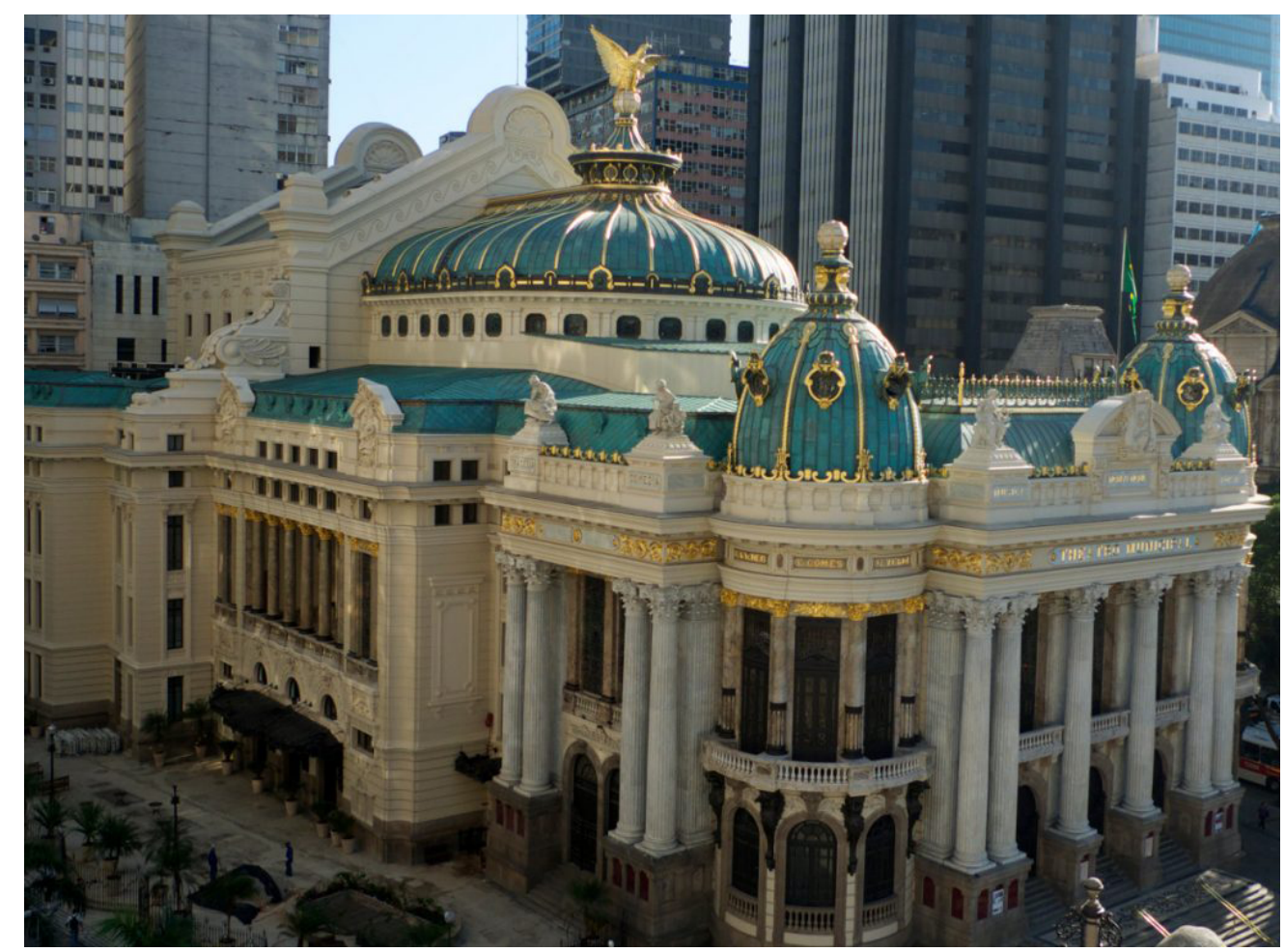




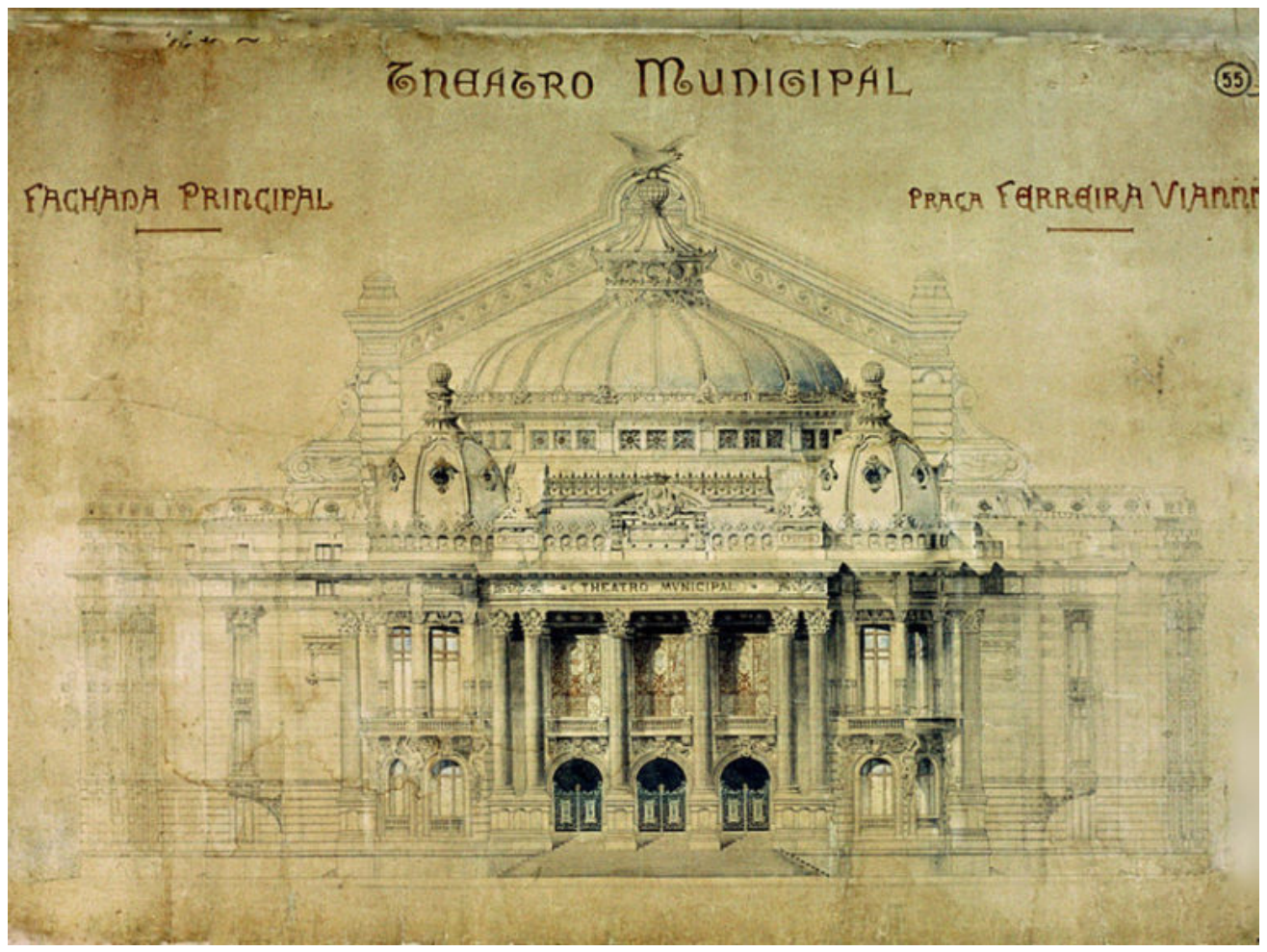

Considerando que qualquer intervenção de restauro deve avaliar a durabilidade dos materiais e está sujeita, portanto, à alteração da matéria, verificase neste exemplo um fenômeno que busca criar uma imagem cromática simulando a cor original e ignorando o tempo decorrido, o que pode ser descrito como uma proposta de "rejuvenescimento" forçado, em que predomina o valor de novidade:

\footnotetext{
Esse "rejuvenescimento" forçado de nossos bens culturais faz parte, na verdade, de um fenômeno mais amplo, que se acentuou em tempos recentes: a busca de juventude a qualquer preço, que também acaba por repercutir no trato dos monumentos históricos, que passam a ter a obrigação de parecer novos. ${ }^{34}$
}

Essa natureza de valor já é conhecida, pois foi analisada e descrita em 1903 pelo austríaco Alois Riegl,35 que realizou um aporte teórico sobre as significações relativas ao conceito de monumento histórico, articulando a renascença e a modernidade às alternativas de valorização. $\bigcirc$ desejo de renovação, como percebido por Riegl, ${ }^{36}$ acompanha a trajetória do homem, desde tempos muito remotos, e refere-se a uma satisfação do espírito que não demanda conhecimento específico para existir.
34. Kühl, op. cit., p. 321.

35. Riegl (2006).

36. Ibid.

Figura 2 - Projeto final para $\circ$ Teatro Municipal em 1904. Fonte: Disponível em: <https://bit.ly/3oCRxWB>. Acesso em: 06 out. 2021. Crédito: PREFEITURA do Distrito Federal (RJ). 
Outro exemplo pertinente que ilustra o segundo dos três paradigmas subjacentes às intervenções cromáticas em superfícies arquitetônicas de valor patrimonial, é o conjunto de edificações, atualmente pintadas na cor amarela, tombadas em esfera estadual na cidade de Vitória, no Espírito Santo. Uma delas, - Teatro Carlos Gomes, erguido no final da década de 1920, apresentava, após sua construção, as cores de suas fachadas em um tom claro, talvez branco, mas certamente com pouca saturação de matiz (Figura 3).

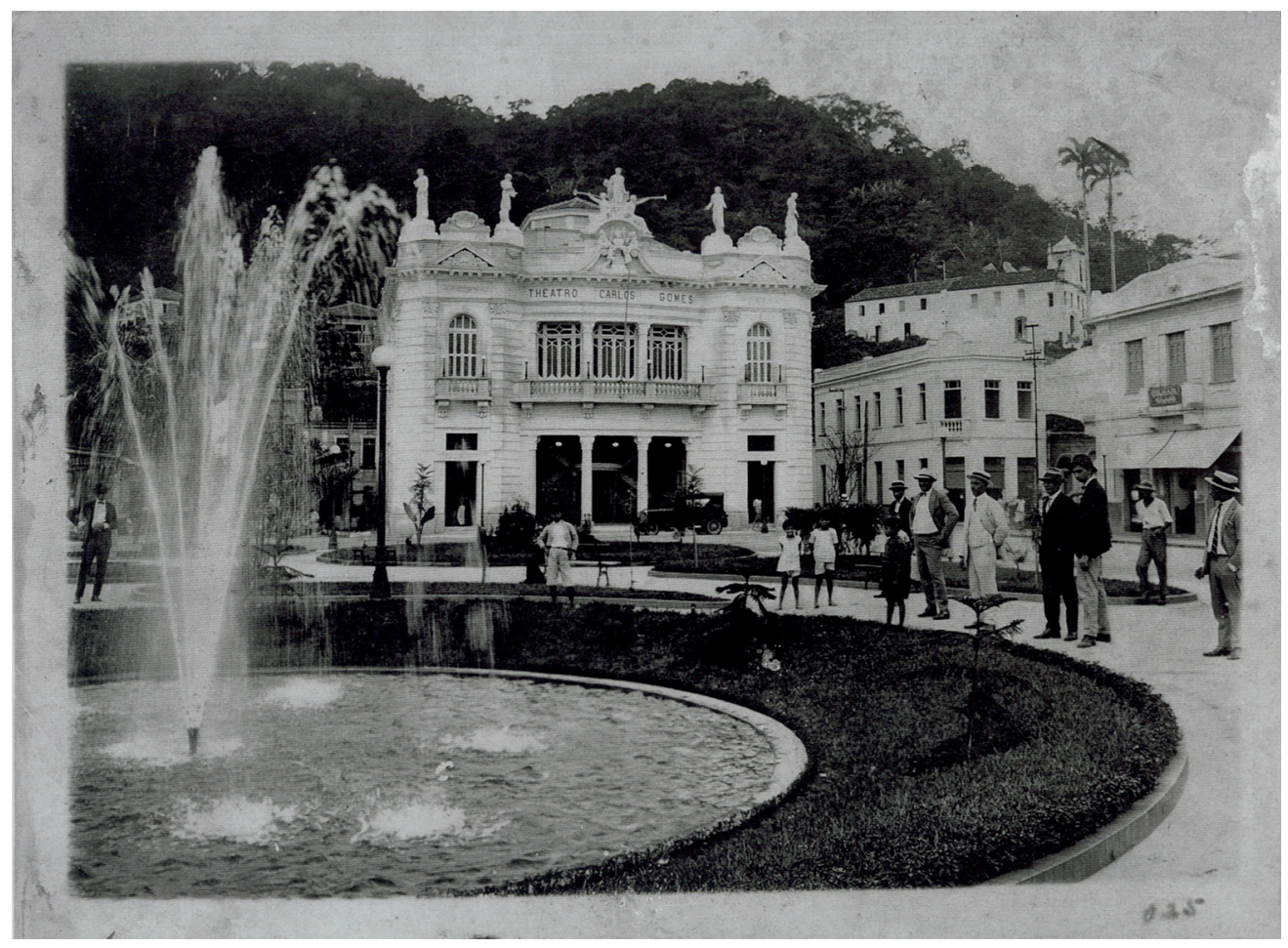

Figura 3 - Teatro Carlos Gomes, em Vitória (ES), fotografia de meados da segunda década do século XX. Fonte: Acervo Superintendência do Iphan no Espírito Santo.

No entanto, na última restauração, optou-se por pintá-lo de um tom de amarelo saturado (Figura 4), matiz que também foi utilizado para pintar outras edificações tombadas em Vitória, o que configura uma estratégia que parece tentar fortalecer uma relação entre as edificações ecléticas e a cor amarela. Ressalta-se que, apesar de haver registro do período de construção do Teatro Carlos Gomes, em Vitória (ES), não se trata aqui de debater a favor de um retorno às cores originais, mas de salientar que tais intervenções revelam uma tentativa de criação de narrativa imagética fundamentada em uma espécie de historicismo anacrônico, narrativa que não encontra aporte no passado e sim na imagem criada desse passado. De fato, a cor amarela, de intensa saturação, tem sido amplamente 
utilizada em restaurações arquitetônicas de edificações ecléticas ocorridas nas últimas décadas, mas esse paradigma que utiliza o passado de maneira alegórica oscila de acordo com a relação imagética em voga no momento. Ele também pode ser identificado nas intervenções cromáticas em edificações remanescentes do período colonial brasileiro, nas quais se retira o colorido que as paredes passaram a apresentar ao longo dos séculos pintando-as com tinta branca para imitar a cal. Na escala urbana, quando os bens edificados compõem uma unidade coesa, é possível ver o alargamento desse paradigma, o que constitui uma terceira atitude constatada por meio das cores do patrimônio edificado.

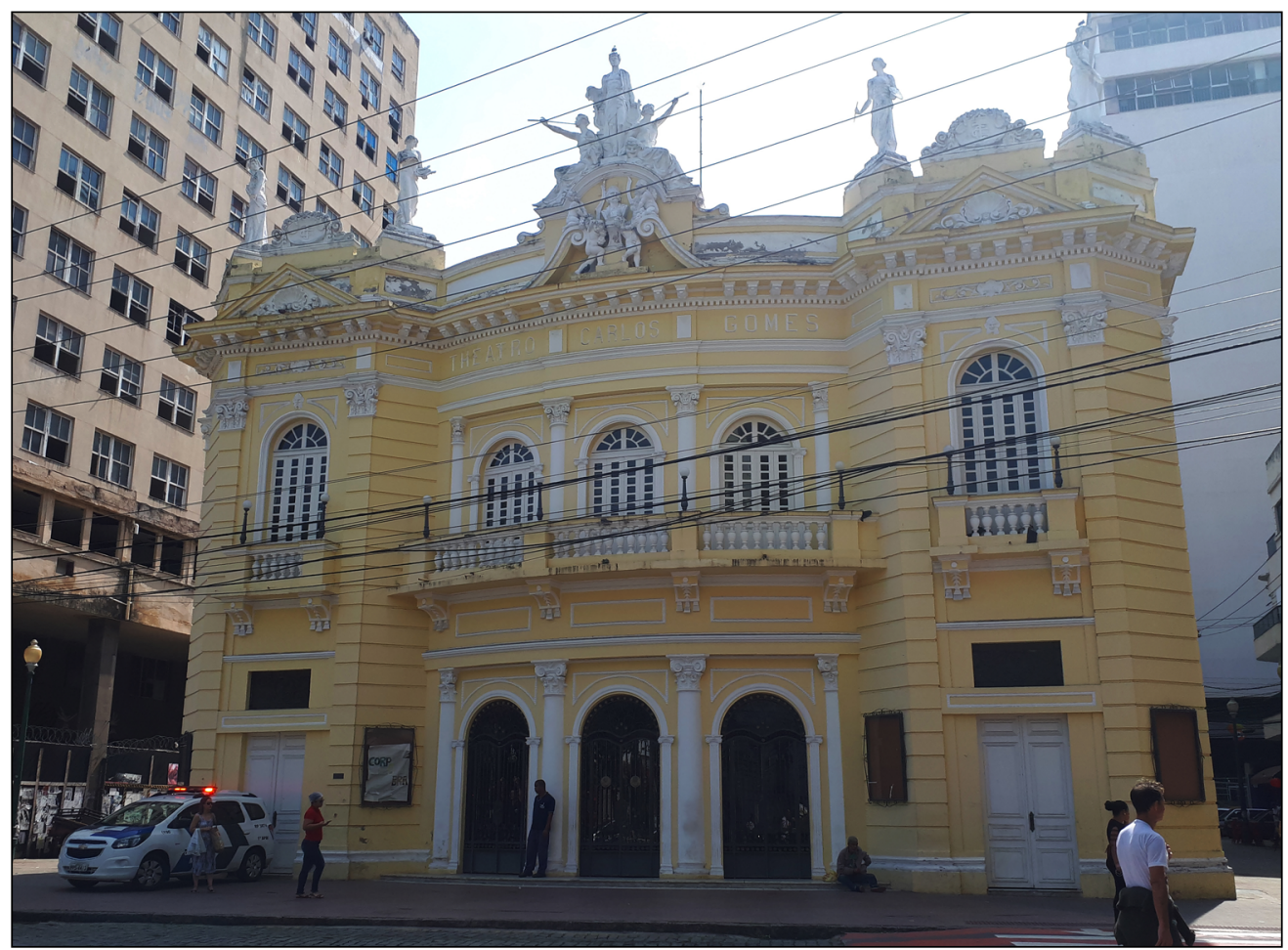

Figura 4 - Teatro Carlos Gomes, em Vitória (ES), 2019.

Assim, o terceiro paradigma contemporâneo que influencia diretamente as intervenções cromáticas no patrimônio edificado brasileiro configura-se por meio do turismo cultural. Nesse cenário, verifica-se que cidades históricas de grande expressão nacional, cuja ocupação iniciou-se no período colonial, apresentam hoje suas fachadas predominantemente brancas com janelas pintadas em tons coloridos e saturados, como Paraty, no estado do Rio de Janeiro. Destacase que embora muitas dessas edificações tenham chegado à contemporaneidade com cores em suas superfícies arquitetônicas, intervenções de restauro optaram 
por pintá-las de branco e com as esquadrias coloridas, o que revela tentativas de retornar à suposta originalidade desatentas ao pressuposto teórico de que o tempo é irreversível (Figura 5). Trata-se, na realidade, da forte influência do turismo cultural, que ignora o patrimônio como estratificação.

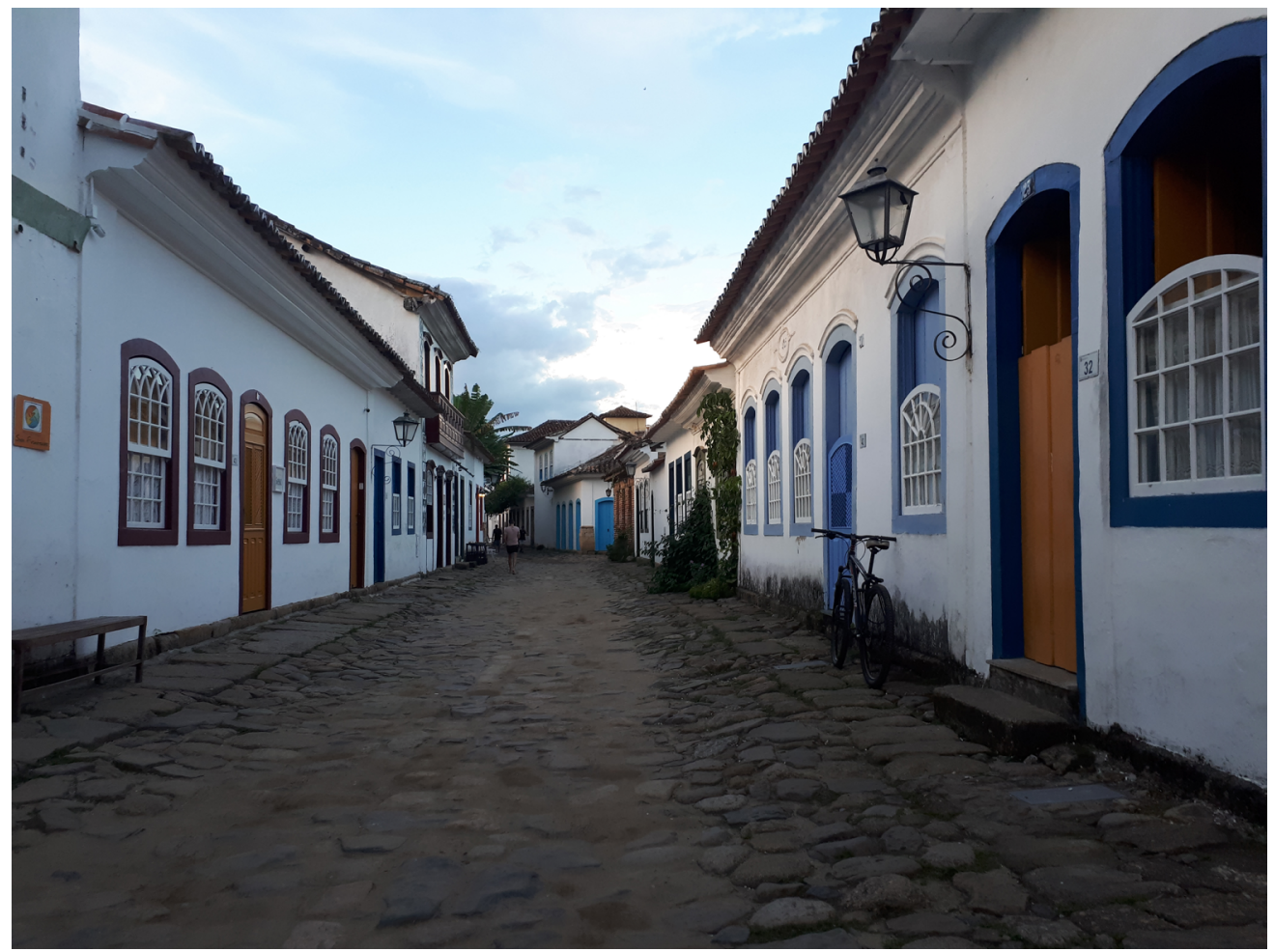

Figura 5 - Centro histórico de Paraty, 2019.

É importante salientar que, na história da arquitetura, as cidades desenvolvem culturas arquitetônicas e cromáticas próprias em sua trajetória temporal, de modo que as cores das superfícies alteram-se à medida que a cidade também muda. Assim, em sua relação fenomenológica, as cores, ao longo da história da humanidade, sempre refletiram os territórios, criando ambiências únicas e processos de identificação por meio de sua relação cromática coerente com sua unidade espaço-temporal. Apesar da importância das cores das superfícies arquitetônicas enquanto elementos de valor histórico e de identidade territorial, o paradigma do turismo cultural influencia o contexto urbano brasileiro de maneira abrangente e totalizante, tornando espaços geográficos bastante distintos em imagens repetitivas. Portanto, ao analisar experiências brasileiras, cabe reforçar a necessidade de reflexões sobre o tema quanto à padronização cromática no patrimônio cultural edificado, para não culminar na busca de um historicismo 
anacrônico, ou em uma simulação de rejuvenescimento forçado (que tampouco respeita as estratificações do tempo) ou ainda no turismo cultural que engole as singularidades locais e não almeja preservar os valores territoriais.

Os exemplos acima demonstrados ilustram atitudes que estruturam, implicitamente, as decisões projetuais no âmbito das cores dos bens culturais edificados, e são significativos para analisar a relação do patrimônio cultural com a problemática das imagens e dos simulacros. ${ }^{37}$ Após a Segunda Guerra Mundial, o conceito de imagem tornou-se amplamente explorado como recurso de planejamento inserido na lógica capitalista do consumo. ${ }^{38}$ As imagens passam a ser produzidas com base em outras imagens, em um processo de simulação que culmina na sua banalização e na perda de referenciais verdadeiros. ${ }^{39}$ Küh|l0 já havia alertado para essa condição contemporânea quando abordou transformações cromáticas em conjuntos ou centros históricos. Ele observou que, em algumas situações, tais intervenções buscam voltar às cores originais e trazer para a contemporaneidade uma suposta imagem histórica que nunca existiv; em outros casos, utilizam cores fortes preponderantes, o que cria uma infantilização da imagem que não tem coerência formal com sua própria arquitetura e, consequentemente, dificulta tanto a leitura quanto a fruição do bem cultural, além de revelar, simultaneamente, um intenso processo de turismo cultural.

Diante de tais restaurações, levanta-se o questionamento se essas intervenções cromáticas refletem os princípios do restauro crítico e do discurso consolidado nas principais vertentes teóricas no Ocidente. Infelizmente, os exemplos e a argumentação aqui realizada demonstram que não; na verdade, existe uma semelhança nas motivações que aparentemente conduzem as decisões sobre as intervenções cromáticas independentemente das particularidades de cada caso e de cada lugar. Nesse cenário, este artigo discute as cores das superfícies arquitetônicas e seu lugar na produção contemporânea de narrativas imagéticas criadas para monumentos ou sítios urbanos, reconhecidos e protegidos pela legislação brasileira enquanto patrimônio cultural. Busca-se retomar, no debate teórico, a questão das cores das superfícies arquitetônicas dos bens culturais, cuja decisão projetual, longe de ser aspecto secundário, hoje reflete atitudes estruturantes relacionadas a três paradigmas identificados: o culto ao valor de novidade, tendências cromáticas como o uso do amarelo na arquitetura historicista $e$, na escala urbana, a imposição do turismo cultural.

Para tanto, as questões que este artigo levanta agrupam-se em torno do conceito de paradigma. O termo, embora polissêmico, consiste em uma tentativa de explorar o sentido de convenções coletivas estabelecidas por meio da noção de valores compartilhados por uma coletividade. Esse sentido pressupõe, 
41. Kuhn, op. cit.

42. O termo zeitgeist pode ser traduzido como o "espírito da época" e, portanto, único e exclusivo do tempo presente (NESBITT, 2008).

43. Magar Meurs e Schneider Glandz (2018).

44. Debord (2007, p. 14). portanto, a fundamentação conceitual das metáforas envolvidas, bem como a identificação dos valores coletivos. $O$ termo paradigma, segundo a noção de Kuhn, ${ }^{41}$ é incorporado nesta pesquisa e consiste em representações do mundo que são interpretadas e reconhecidas de maneira mais ou menos homogênea por uma comunidade. Assim, paradigma diz respeito às maneiras com que a consciência humana situa suas tomadas de decisão e está diretamente ligado ao tempo presente, ao zeitgeist. ${ }^{42}$

Portanto, busca-se com este artigo contribuir para fortalecer os fundamentos teóricos da prática da restauração de bens culturais no Brasil. Sobre a importância de construir uma forte base teórica, Magar Meurs e Schneider Glandz ${ }^{43}$ salientam a dificuldade dentro do próprio campo da preservação de bens culturais, pois muitos profissionais acreditam que a teoria estaria inserida somente no campo deontológico da disciplina, abrangendo apenas julgamentos sobre intervenções, quando na realidade ela é um caminho conceitual que não atua unicamente como apoio de ações de caráter prático. Isto é, as autoras reforçam a necessidade de estruturas argumentativas para além de conclusões normativas.

Frente ao exposto e considerando que a cor é determinante para a orientação humana, bem como para as inerentes conexões entre o patrimônio edificado e os indivíduos, qual o papel das cores das superfícies arquitetônicas na preservação dos bens culturais edificados? Se cada caso depende do juízo crítico e dos valores inerentes ao bem e ao contexto, e se não se deve buscar criar um aspecto de novo, como se fosse possível com isso retornar a uma suposta imagem original, como esse discurso é materializado na prática das intervenções cromáticas em bens culturais brasileiros? Tais práticas refletem o enquadramento teórico ou não? Essas são algumas das perguntas que norteiam a reflexão deste artigo, cuja pesquisa, embora esteja fundamentada em uma vasta bibliografia, estrutura-se a partir do que Debord ${ }^{44}$ definiu como espetáculo, pois ele define que "não é um conjunto de imagens, mas uma relação social entre pessoas, mediatizada por imagens".

Diante desse cenário, assumindo que o presente carrega consigo não só o passado, mas também o futuro e, ainda, embasados na crença de que as possibilidades de respostas a essas perguntas dependem da construção de uma forte base teórica, almeja-se que este artigo contribua para fortalecer os princípios teóricos para uma práxis da conservação, reforçando que não são teorias que tomam decisões e sim profissionais, que devem ter sólida formação e exercer constante reflexão teórica sobre os limites das intervenções em bens culturais. 
Entender o contexto da arquitetura no período que sucedeu meados da década de 1960 é determinante para analisar o modo atual como a sociedade contemporânea brasileira lida com a preservação do patrimônio cultural. Nesse momento, a teoria da arquitetura absorveu a influência da fenomenologia cunhada por Edmund Husserl no início do século XX e pelo posterior pensamento de Martin Heidegger, bem como ganham força correntes teóricas que colocam em pauta a importância da história. ${ }^{45}$ Em parte também como crise do movimento moderno, a história dos lugares passa a ser algo buscado nas intervenções e na criação arquitetônica, de modo que perdem força o international style e a estandardização. Sabe-se que a reação crítica à produção arquitetônica das primeiras décadas do século XX busca interromper a noção de ruptura com a história que foi preconizada pelos principais expoentes da arquitetura moderna. Esse contexto é narrado por Montaner ${ }^{46}$ quando ele observa que a crítica arquitetônica, a partir de 1960, passou a resgatar a história como fonte primária para a criatividade na arquitetura. Nesse âmbito, o autor constata que a defesa da tradição acabou gerando um paradoxo, pois as obras arquitetônicas com referência à tradição tornavam-se então mais modernas que as obras inseridas no paradigma do movimento moderno.

Simultaneamente a esse cenário, a partir de 1970 no Brasil, as questões patrimoniais passam a se inserir com maior destaque no debate e também na dinâmica urbana, devido às várias intervenções em cidades históricas ou monumentos isolados. Por um lado, há uma experiência positiva em trazer uma dimensão sensorial e histórica para a arquitetura como ocorreu em meados das décadas de 1960 e 1970; em contrapartida, esse processo na contemporaneidade muitas vezes tem estimulado a criação de uma imagem histórica de bens de valor patrimonial que acabaram perdendo suas reais referências culturais.

Nas últimas décadas, discursos relativos à preservação do patrimônio - seja arquitetônico e urbanístico, seja ambiental ou cultural, material ou imaterial ganham a mídia e aparecem cada vez mais intensos na sociedade, aumentando tanto o número de profissionais envolvidos com a preservação do patrimônio quanto o reconhecimento por parte da população da importância de preservar os testemunhos materiais do passado. A arca de Noé - termo cunhado por Choay ${ }^{47}$ para designar o extenso número de bens culturais - aumenta progressivamente, uma vez que os processos de patrimonialização dos remanescentes do passado tornaram-se um fenômeno frequente na sociedade desde as últimas décadas do século XX. Os bens materiais e as referências imateriais do passado são 
reestruturados de forma que adquirem novos significados, destinados a balizar as identidades locais e a construção da memória coletiva. Os bens imóveis, reconhecidos como obra de arte e, portanto, patrimônio, imersos nas tramas sociais e políticas do presente, tornam-se símbolos para cumprir novas funções. Dessa forma, o patrimônio cultural adquire papel essencial na lógica da indústria cultural, pois auxilia a formação de imagens que, mais do que atuarem como suporte às memórias enquanto afirmação dos valores territoriais, exercem papel determinante na atividade turística e na invenção das tradições.

Nesse panorama, com as atuais tendências de valorização das cidades, orientadas segundo as estratégias do planejamento urbano, tanto por parte do Estado quanto dos empreendimentos privados, o patrimônio ganhou destaque e, no discurso, passou a ser defendido como referência basilar da história de uma cidade, da memória do lugar, e também como um importante recurso econômico voltado às atividades da indústria cultural. Com a valorização da cultura da imagem e do entretenimento, é fácil compreender como o turismo, associado ao patrimônio cultural, passou a ser uma ótima opção para o mercado e para as políticas públicas urbanas.

Em um momento em que o lazer e o espetáculo assumem posição estratégica no planejamento das cidades, as questões patrimoniais passam a ser elemento essencial no ordenamento do território apoiado na premissa de desenvolvimento local. O patrimônio cultural adquire status e, com isso, transforma-se em significativo recurso econômico para as cidades privilegiadas que o possuem. Nessa lógica, tanto o Estado quanto a iniciativa privada passam a buscá-lo, valorizá-lo e incentiválo. Com efeito, a sociedade contemporânea, inserida na lógica capitalista do consumo, trata a imagem como significativo recurso de projeto, o que culmina em uma cultura que a valoriza como recurso cênico e, consequentemente, conduz à perda de antigos referenciais do homem.

Para entender melhor esse cenário, é pertinente a reflexão de RochaPeixoto, ${ }^{48}$ que define três bases epistemológicas para analisar as relações entre história e arquitetura e argumenta que as décadas seguintes a 1960 proporcionaram novas abordagens dos conceitos de cultura e de história. A terceira dessas bases, situada no período consecutivo ao movimento moderno, é chamada de modo historiográfico-culturalista e concebe a história como uma narrativa do tempo. ${ }^{49}$ Nesse momento, ele observa que a historiografia não tem mais uma única finalidade, isto é, ela rompe com a ideia de explicações tołais e almeja explicações parciais para múltiplos fatos. Por outro lado, ainda observa que toda narrativa dependerá de um elemento determinante para compor os fatos: o mito, entendido enquanto força de caráter simbólico-imagético. ${ }^{50}$ 
A imagem é, então, para Rocha-Peixoto, ${ }^{51}$ real enquanto imagem e mito enquanto narrativa do passado. Ela se altera enquanto imagem, pois reflete os valores e as construções sociais do homem contemporâneo, diferentemente do passado, que não existe mais e não pode ser resgatado. Por outro lado, no patrimônio cultural o que se preserva, no termo consolidado por Brandi ${ }^{52}$ e pelo restauro crítico, é justamente a imagem da obra de arte. Isto é, ainda que a leitura e a compreensão das obras sejam fenomenológicas, deve-se preservar a imagem que levou o bem a ser objeto de reconhecimento como patrimônio cultural. É, portanto, um paradoxo pensar que a manutenção da imagem seja ao mesmo tempo o objetivo da preservação e um arquétipo do presente, já que ela inadvertidamente se altera em razão dos valores sociais contemporâneos.

conceito de imagem fundamenta-se na representação de algo e, apesar de ser amplo, pode ser compreendido na descrição de Chavi quando afirma que as imagens "oferecem-nos um análogo das coisas, seja porque estão no lugar das próprias coisas, seja porque nos fazem imaginar coisas através de outras". 53 Para a autora, há uma distinção clara entre imagem e percepção, pois a primeira é uma espécie de rastro da segunda. Além disso, a imagem é um processo que se estrutura e se concretiza na realidade por meio dos signos e apresenta "um poder especial: torna presente ou presentifica algo ausente, seja porque esse algo existe e não se encontra onde estamos, seja porque é inexistente". ${ }^{54}$

A ideia da imagem da cidade, ou seja, um estudo envolvendo sua fisionomia, embora tenha sido analisada por diversos autores - entre eles Camillo Sitte, que no século XIX escreveu o livro A construção da cidade segundo seus princípios artísticos -, foi analisada de maneira mais profunda a partir dos estudos do arquiteto e urbanista Kevin Lynch. Em seu livro A imagem da cidade, publicado em 1960, Lynch ${ }^{55}$ aborda a percepção do homem sobre três cidades estadunidenses, a fim de entender como as pessoas estruturam essas cidades em seus pensamentos. Para Lynch, "as imagens ambientais são o resultado de um processo bilateral entre o observador e seu ambiente". 56 Segundo o autor, uma imagem do ambiente pode ser decomposta em três elementos que, embora possam ser analisados separadamente, na prática sempre se manifestam juntos: a identidade, a estrutura e o significado. Após seus estudos, a ideia da imagem da cidade foi novamente colocada em discussão nas pesquisas que envolvem o desenho urbano e a percepção ambiental. Características espaciais próprias de cada lugar passam a ser buscadas como reflexo da crise do movimento moderno, quando a arquitetura busca a história do lugar e a relação de identificação do homem com o espaço
51. Ibid.

52. Brandi (2008).

53. Chaui (1998, p. 132).

54. Ibid., p. 133.

55. Lynch (2010).

56. Ibid., p. 7. 
57. Ibid., p. 11.

58. Nesbitt, op. cit.

59. Lynch, op. cit.

60. Nesbitt, op. cit.

61. Ibid.

62. Carsalade, op. cit.

63. Ibid.

64. Ibid., p. 117.

65. Ibid., p. 365. urbano. Nesse contexto, ganham força os estudos acerca da importância da imaginabilidade nos processos afetivos entre o indivíduo e a cidade.

A imaginabilidade trata-se da "característica, num objeto físico, que the confere uma alta probabilidade de evocar uma imagem forte em qualquer observador dado". ${ }^{57}$ Esse conceito também pode ser encontrado na abordagem fenomenológica do arquiteto norveguês Norberg-Schulz. ${ }^{58}$ Assim como Lynch, ${ }^{59}$ Norberg-Schulz, no ensaio intitulado $\bigcirc$ fenômeno do lugar, ${ }^{, 0}$ discorre sobre a necessidade humana de orientação e identificação espacial. Consoante à ideia romana de genius loci sobre - lugar, a arquitetura deve se articular ao local onde está implantada, de maneira a considerar e fortalecer a identificação do usuário com sua cultura e região. ${ }^{61}$

Tais aspectos fenomenológicos conduzem a uma questão central sobre as imagens: elas não são criadas na percepção humana apenas pelos seus aspectos visuais; logo, reduzir a arquitetura ao conceito de imagem é um equívoco que deve ser desmistificado. Pressupondo, então, que a arquitetura não se esgota na imagem, antes de discorrer sobre a relação entre as cores das superfícies arquitetônicas e as imagens urbanas e os significados atribuídos ao patrimônio cultural, é necessário refletir sobre como o conceito de imagem é abordado na teoria do restauro, pois é dessa discussão que emerge a centralidade deste artigo acerca dos paradigmas contemporâneos nas cores dos bens culturais edificados, já que realizar uma intervenção de restauro requer uma base teórica com princípios sólidos. Nesse sentido, enfatiza-se a argumentação de Carsalade, ${ }^{62}$ que trabalha a questão da imagem no patrimônio sempre reforçando a bipolaridade da arquitetura. Entendida simultaneamente como obra de arte e objeto de uso, a arquitetura é tema importante da reflexão desse pesquisador brasileiro, cuja análise sobre essa dualidade afirma a existência de um distanciamento entre a arquitetura e as outras possibilidades de expressão artística visual no âmbito da imagem. Para Carsalade, ${ }^{63}$ a problemática da imagem arquitetônica não se esgota na figuração, pois não pode ser entendida como mimese ou metonímia, na medida em que a "imagem da arquitetura [é] o mundo que ela cria e que materializa a cultura e as instituições". ${ }^{64}$

Partindo da fenomenologia, da hermenêutica e influenciado pelo pensamento de Sartre, que afirma que "a imagem não é alguma coisa que está na consciência, não é um estado psíquico [...] A imagem, ao contrário, é um certo tipo de consciência, é um ato intencional e não uma coisa", 65 o autor argumenta sobre a impossibilidade de desvinculação da matéria com a imagem e discorda, de certa maneira, do pensamento brandiano. Ao analisar a obra de Brandi, ele observa que sua teoria da restauração, ao estabelecer certo privilégio da instância estética sobre a histórica, supõe uma permanência atemporal da arte, que superaria, assim, a própria história. No entanto, a preocupação de Brandi com a imagem culmina em contradições 
dentro da própria teoria, sendo uma das primeiras divergências justamente a problemática da desvinculação da matéria (suporte) com a imagem (conteúdo). .60

Para o autor brasileiro, é intrínseca a relação entre materialidade e imagem, na medida em que a própria matéria é parte integrante da obra de arte e não somente o meio físico da veiculação da imagem. Em termos práticos, alterações na matéria reverberam na imagem. Outro aspecto das reflexões de Carsalade ${ }^{67}$ acerca do conceito de imagem na obra de Brandi68 consiste no argumento de que a teoria brandiana reforça a diminuição da presença do sujeito na obra, como se fosse possível que esta se perpetue no tempo, de modo que se idealiza uma restauração em que o restaurador é neutro e não coautor da obra. Nesse âmbito, há na reflexão de Carsalade ${ }^{69}$ pontos em comum com vertentes da crítica do restauro que abordam justamente a dificuldade de uma atitude centrada na imagem e, portanto, visual e atemporal, sem analisar a percepção do sujeito sobre a obra.

Essas conexões possibilitam afirmar que a arquitetura não se esgota na imagem e engloba um sentido amplo de orientação e identificação, abrangendo também outros sentidos para além da visão. Sem esquecer-se desse fato primordial, Kühl70 abordou, no início deste século, a complexidade do tratamento que deve ser dado às superfícies arquitetônicas e chamou a atenção para uma questão fundamental a ser analisada nas intervenções cromáticas: a necessidade de interpretar a obra como imagem figurada. Essa reflexão também é encontrada na análise de Carsalade que valida uma instância cultural ao afirmar que:

\footnotetext{
Tanto as instâncias histórica e artística estão subordinadas à "instância cultural e a diferentes "subculturas", as quais valorizam segundo o pensamento da época e a pertença a diferentes tradições. Não dá mais para entender o restauro desvinculado dessa tradição e dessa condição cultural" ${ }^{71}$
}

Tais questões mostram com clareza o restauro como processo crítico, que é "ligado às ciências sociais aplicadas nos campos da teoria da percepção e da filosofia estética, da análise histórico-estilística, e de instrumentos presentes na prática da sociologia, tais como a intersubjetividade e os consensos, dentre outros". ${ }^{72}$ Além da chamada instância cultural, ${ }^{73}$ o amadurecimento da dicotomia expressa por Brandi ${ }^{74}$ por meio das instâncias estética e histórica encontra na chamada instância textual uma possibilidade contemporânea de leitura e análise do patrimônio edificado. ${ }^{75}$ Os estudos de Dalla Negra ${ }^{76}$ centram-se não só nos aspectos conceituais, mas englobam o plano operativo da prática de restauro. A instância textual, para o pesquisador e professor italiano, deve ser entendida em sentido orgânico e implica
66. Ibid.

67. Ibid.

68. Brandi (2008).

69. Carsalade, op. cit.

70. Kühl, op. cit.

71. Carsalade, op. cit., p. 395.

72. Ibid., p. 393.

73. Ibid.

74. Brandi (2008).

75. Dalla Negra (2015).

76. Ibid. 
77. Cf. Dalla Negra (2020, informação verbal). DALLA NEGRA, Ricardo. Architettura e Preesistenze. Palestra realizada no $4^{\circ}$ Simpósio Científico do Icomos-Brasil, [S. l.], nov. 2020. (Informação verbal).

78. Vitiello (2011).

79. Carsalade, op. cit.

80. Ibid.

81. Debord, op. cit.

82. Baudrillard, op. cit.

83. Ibid.

84. Jeudy (2005).

85. Debord, op. cit. em três corolários: a exigibilidade do texto, o respeito pela autenticidade da matéria e o respeito pela forma. ${ }^{77}$ Esse deslocamento da questão da imagem para o texto vem acompanhado da noção ampla de texto e contexto, como discorre também Vitiello ${ }^{78}$ ao entrar no tema da cor das superfícies arquitetônicas dos monumentos e observar a impossibilidade de desassociar o aspecto cromático da imagem urbana do contexto em que os monumentos estão inseridos.

Nesse âmbito, ambos dialogam contra uma ideia de imagem enquanto epifania, isto é, como se a obra apresentasse uma verdade, uma aura e um reconhecimento imanente a ela. ${ }^{79}$ É, preciso, então, deslocar a noção de permanência e atemporalidade da obra de arte (e da arquitetura) para uma relação fenomenológica que englobe tanto o sujeito quanto os valores atribuídos ao patrimônio edificado, ${ }^{80}$ de maneira a fugir de processos globalizantes e excludentes marcados pelo capitalismo, pelo mito da sedução da imagem e pelo consumo cultural elitista.

Sob outra perspectiva, Debord ${ }^{81}$ também constrói sua crítica à produção de imagens e à sedução da cultura do espetáculo, que opera a partir de uma relação social entre a produção e o consumo mediado por imagens e, consequentemente, desloca-se da condição de vivência para a condição de representação, em que a cultura torna-se uma mercadoria. Baudrillard ${ }^{82}$ foi além ao analisar o modo como a contemporaneidade incorpora a questão da imagem e nos revela a centralidade de signos e símbolos em oposição aos significados, afirmando que nossa sociedade instituiu uma simulação da realidade por meio de simulacros. Isto é, a cultura do simulacro cria cópias para simular um elemento, artefato ou realidade que nunca existiu. ${ }^{83}$ Essa reflexão é pertinente ao analisarmos as cores contemporâneas das superfícies arquitetônicas em bens culturais edificados - tão iguais, em contextos urbanos e geográficos tão distintos.

De maneira semelhante, Jeudy ${ }^{84}$ alertou sobre a homogeneização dos bens culturais, o que contribui para redução de seu papel simbólico e seus possíveis significados. No âmbito urbano, trata-se de um processo paradoxal, segundo o autor, na medida em que há, dentro do planejamento voltado ao turismo, a intenção de criar uma imagem própria de cada cidade histórica, mas, em contrapartida, culmina nas imagens cada vez mais parecidas de cidades e núcleos urbanos tão distantes geograficamente.

Outro paradoxo surge quando se reflete sobre a condição do patrimônio cultural enquanto imagem e simulacro, pois, se a sociedade narrada por Debord ${ }^{85}$ é midiatizada e movida pelo capital, o bem cultural se transforma na própria imagem. Ele é, portanto, o espetáculo e a mercadoria. Devido ao intuito de simular uma imagem, o patrimônio torna-se, de fato, o simulacro de si próprio. Inseridas 
nesse contexto, as cores das superfícies arquitetônicas do patrimônio cultural exercem papel determinante e essencial na imagem do bem que passa a vigorar e pode-se afirmar que os três paradigmas que estão na base das intervenções cromáticas não correspondem a fenômenos isolados, pois compartilham tanto o paradoxo da imagem quanto o mito da estratégia de sedução.

Assim, de forma geral, essas contradições reforçam a dificuldade de abordar o restauro e a problemática das imagens de um ponto de vista unicamente objetivo e científico, pois qualquer intervenção de restauro ocorre em função de uma reinterpretação. Assim, os bens culturais estão continuamente sujeitos a serem alterados e reinterpretados, a despeito da utopia de permanência da imagem enquanto conceito estático. ${ }^{86}$ Trata-se de um paradoxo pensar que a imagem da obra de arte (e, portanto, do patrimônio cultural) deve ser transmitida ao futuro, pois esta é sentida e interpretada a partir dos aspectos culturais de cada sociedade.

Quanto às cores das superfícies arquitetônicas de bens edificados, no século XXI quase não se vê mais a "geografia da cor", 87 cuja problemática tem sido discorrida por Aguiar ${ }^{88}$ ao analisar as cores dos bens e cidades históricas portuguesas. É importante ressaltar que este artigo não busca enfatizar uma nostalgia de um passado e de sua cultura cromática, já que as cores das cidades mudaram sempre que as próprias cidades avançaram em sua trajetória temporal. A problemática não reside na transformação, pois ela é inerente à própria condição humana, e sim na homogeneização dos lugares de valor patrimonial. Vislumbrar novos caminhos é extremamente difícil, pois, no mundo contemporâneo imerso em uma estetização em múltiplas esferas, como imaginar uma possibilidade de criação cromática, tanto estética quanto significativa e coerente com a natureza do bem patrimonial, e, ainda, como incorporá-la nas políticas urbanas de preservação, tão marcadas pelo culto ao efêmero? As possibilidades imaginadas apoiam-se fortemente na consolidação de princípios teóricos e no fortalecimento de políticas locais, gestão urbana e qualidade de vida como base ética, em detrimento da homogeneização ocidental e da primazia do capital.

\section{UMA LEITURA CROMÁTICA CONTEMPORÂNEA}

Até aqui se argumentou sobre os aspectos teóricos que possibilitam analisar a cultura da imagem na prática preservacionista no Brasil contemporâneo e, a esta altura, cabe demonstrar como essas questões são refletidas nas intervenções cromáticas dos bens culturais. A cultura da imagem compreende o desejo de 
89. Riegl, op. cit.

90. Ibid., p. 97. homogeneização (ou seria globalização?) e não é possível a desvincular do fato de que a sociedade é fortemente ligada a valores capitalistas e está sujeita às pressões do poder econômico, o que, por consequência, pressupõe que as culturas sejam usufruídas em qualquer lugar, independentemente do seu território de origem. Portanto, no cerne do problema está a questão econômica e, considerando esse panorama, mostraremos alguns exemplos de cores em arquiteturas acauteladas e quais paradigmas parecem estar por trás das decisões cromáticas.

Nesse sentido, abordaremos primeiramente o paradigma que se configura no valor de novidade, pois tanto a seleção quanto as estratégias de preservação dos bens culturais são determinadas pelos valores sociais compartilhados, assim como pelos desejos dos grupos dominantes. Sabe-se que a relação entre a nova arquitetura e os testemunhos materiais do passado consiste em um processo que oscila ao longo do tempo, sobretudo em razão dos valores culturais vigentes, o que torna uma ilusão formular diretrizes permanentes ou universais. Esse pensamento dialoga com a ideia do restauro crítico e da particularidade caso a caso, que busque analisar os valores para os grupos sociais que compartilham aquele patrimônio cultural.

Para entender o paradigma do valor de novidade, utilizaremos argumentos fundamentados nos estudos de Riegl, ${ }^{89}$ que no início do século XX abordava os valores de época e buscava entender as maneiras com que a sociedade naquele momento se relacionava com seus bens culturais. Em sua análise, ele estabelece que os caminhos para a preservação sejam adotados a partir da identificação dos valores vigentes, denominados por ele de valores de rememoração e valores de contemporaneidade. Este último divide-se em valor de uso e valor de arte, que, por sua vez, subdivide-se em valor de arte relativo e valor de novidade. Interessa-nos na presente discussão justamente discutir o valor de novidade e sua relação com o culto dos monumentos. Nesse sentido, destaca-se a perfeita integridade das formas e cores do monumento como exigência para satisfação desse valor, observando ainda:

[...] para que um monumento que apresente marcas de degradação possa satisfazer ao valor moderno que descrevemos, é necessário, antes de tudo, que se desembarace dos traços de envelhecimento, e que reencontre, por meio da restauração completa de sua forma e cores, o caráter de novidade da obra que acaba de nascer. ${ }^{90}$

Esse é um valor, portanto, moderno e que se contrapõe aos valores de rememoração. De fato, na contemporaneidade observa-se uma forte atitude preservacionista que privilegia a imagem e, por isso, busca criar um cenário e deixa de lado aspectos históricos ou até mesmo estéticos. No entanto, no passado, as edificações com traços que remetessem ao tempo decorrido foram objeto de 
contemplação e atribuía-se um forte significado aos bens culturais relacionado com a antiguidade. ${ }^{91}$ Cabe destacar que mesmo com toda a ambiguidade que o termo antiguidade suscita, o valor de antigo foi uma qualidade subjetiva que transmitia a mensagem do tempo e se conectava com a fruição humana, além de ter conquistado as massas e não apenas os intelectuais. Em 1903, Riegl ${ }^{92}$ analisou e descreveu esse valor e observou como a cultura urbana, naquele momento, estava relacionada com uma imagem de permanência dos monumentos e contemplava uma satisfação estética ligada às marcas da passagem do tempo.

94. Ibid.

95. Ibid.

96. Ibid., p. 91.

97. Ibid.

Entretanto, assim como o valor de antiguidade, também o valor de novidade exercia grande poder sobre a massa populacional e suas relações com o patrimônio edificado. ${ }^{93}$ Inclusive, embora esses dois valores sejam significativos para a população e de fácil compreensão visual, ambos jamais podem coexistir em sua plenitude, já que são substancialmente opostos. ${ }^{94}$ Isto é, o valor de novidade demanda que o bem cultural, por meio de uma restauração de sua forma e cores, tenha uma imagem de obra que acabou de ser erguida, apresentando uma policromia intacta. Dessa forma, ao discorrer sobre o valor de novidade inserido na categoria de valores de contemporaneidade, Riegl${ }^{95}$ reforça que esse valor pressupõe que os monumentos respondam a uma expectativa dos sentidos da mesma maneira que obras novas e modernas. Nesse sentido, ele salienta que:

O valor de contemporaneidade reside nessa propriedade que, com toda evidência, não atribuiu papel nem à antiguidade do monumento, nem ao valor de rememoração que dele decorre. Ao invés de considerar o monumento enquanto tal, o valor de contemporaneidade tenderá, imediatamente, a tomá-lo de forma igual a uma criação moderna recente, e a exigir também que o monumento (antigo) apresente o aspecto característico de toda obra humana em sua gênese: em outras palavras, que dê a impressão de uma perfeita integridade, inatacada pela ação destrutiva da natureza. ${ }^{96}$

Portanto, o valor de novidade ${ }^{97}$ é um valor de contemporaneidade que preconiza a perfeita integridade do bem edificado, inclusive com condições físicas similares às das construções novas. Esse valor também difere do valor histórico observado pelo austríaco, pois não pressupõe, para sua identificação, conhecimentos em história da arte e tampouco se fundamenta na apresentação do bem edificado de maneira que ele pareça pertencer ao passado. Na verdade, diferentemente do valor histórico, o valor de novidade, ao não admitir nenhum vestígio de degradação, busca uma satisfação dos sentidos por meio do preenchimento de lacunas e da reconstituição integral da totalidade do bem, ainda que essa totalidade ou estado físico sequer tenha existido no passado. $\bigcirc$ valor de novidade agrada, assim, a 
98. Ibid., p. 98.

99. Ibid.

100. Ibid., p. 98.

101. Kühl, op. cit. cultura de massa, pois não demanda nada além da sensibilidade para que se constate que aquela materialidade é nova. Nesse sentido, Riegl destaca:

A multidão sempre foi seduzida pelas obras cujo aspecto novo estava claramente afirmado; por consequência, só quis ver nas obras humanas o produto de uma criação vitoriosa, oposta à ação destrutiva das forças da natureza, hostis à criação do homem. Ao olhar da multidão, só o que é novo e intacto é belo. [...] $\bigcirc$ velho, o desbotado, os fragmentos de objetos são feios. ${ }^{98}$

Com efeito, a compreensão do valor de novidade possibilita entender fenômenos contemporâneos oriundos da cultura da imagem e da busca incessante pelo novo que caracterizam a sociedade atual. E, assim, mais de um século depois, esse valor demonstra-se continuar tão absoluto quanto no início do século XX. $\bigcirc$ curioso é que o valor de novidade narrado por Rieg ${ }^{199}$ não se tratava, naquela época, de um valor que o autor percebeu ser influente somente no início do século XX, pois, para ele, já existia havia muitos séculos na história humana e permaneceria exercendo forte influência por muitas décadas, na medida em que "essa atitude milenar, que atribui ao novo incontestável superioridade sobre o velho, é tão solidamente ancorada que não poderá ser extirpada no espaço de algumas décadas". 100 Não é difícil perceber que esse valor de novidade mantém-se forte na contemporaneidade, quando o novo é aclamado em vários aspectos. Cabe salientar que esse paradigma, ainda que inicialmente pareça se vincular somente à problemática da pátina, a extrapola ao refletir a criação de uma narrativa imagética que simula um frescor de novidade para estimular o patrimônio como consumível. Nota-se, nesse sentido, que as cores arquitetônicas hoje, mais do que representar a cultura cromática de uma época, passam a refletir não só um "rejuvenescimento" artificial, mas também as influências das telas e da saturação das cores do espaço virtual. Kühl101 discorre sobre o fenômeno contemporâneo da vontade de juventude artificial em várias áreas, inclusive no patrimônio cultural edificado, e constata que no tratamento dado às superfícies dos monumentos predominam repinturas aleatórias e muitas vezes sem qualquer preocupação em preservar as marcas da passagem do tempo, em detrimento de um processo histórico-crítico. A autora salienta ainda prevalecer uma espécie de "rejuvenescimento" forçado do patrimônio cultural, que se insere em um processo mais amplo que é justamente a busca da juventude em diversas esferas.

Alguns exemplos possibilitam visualizar a questão, especialmente ao se constatar a adição de cores vibrantes e com aparência de superfícies arquitetônicas novas, que substituem a pátina e as texturas irregulares características das edificações históricas. Nesse cenário, uma das edificações do sítio histórico de Santa Leopoldina, 
localizado no estado do Espírito Santo e tombado pelo Conselho Estadual de Cultura, ilustra a situação, na qual edificações ecléticas erguidas no final do século XIX passam a ter na contemporaneidade novas pinturas em cor saturada (Figura 6). Notase que a antiga textura da materialidade, irregular e com a característica da cal, foi trocada por um reboco bastante liso e totalmente homogêneo.

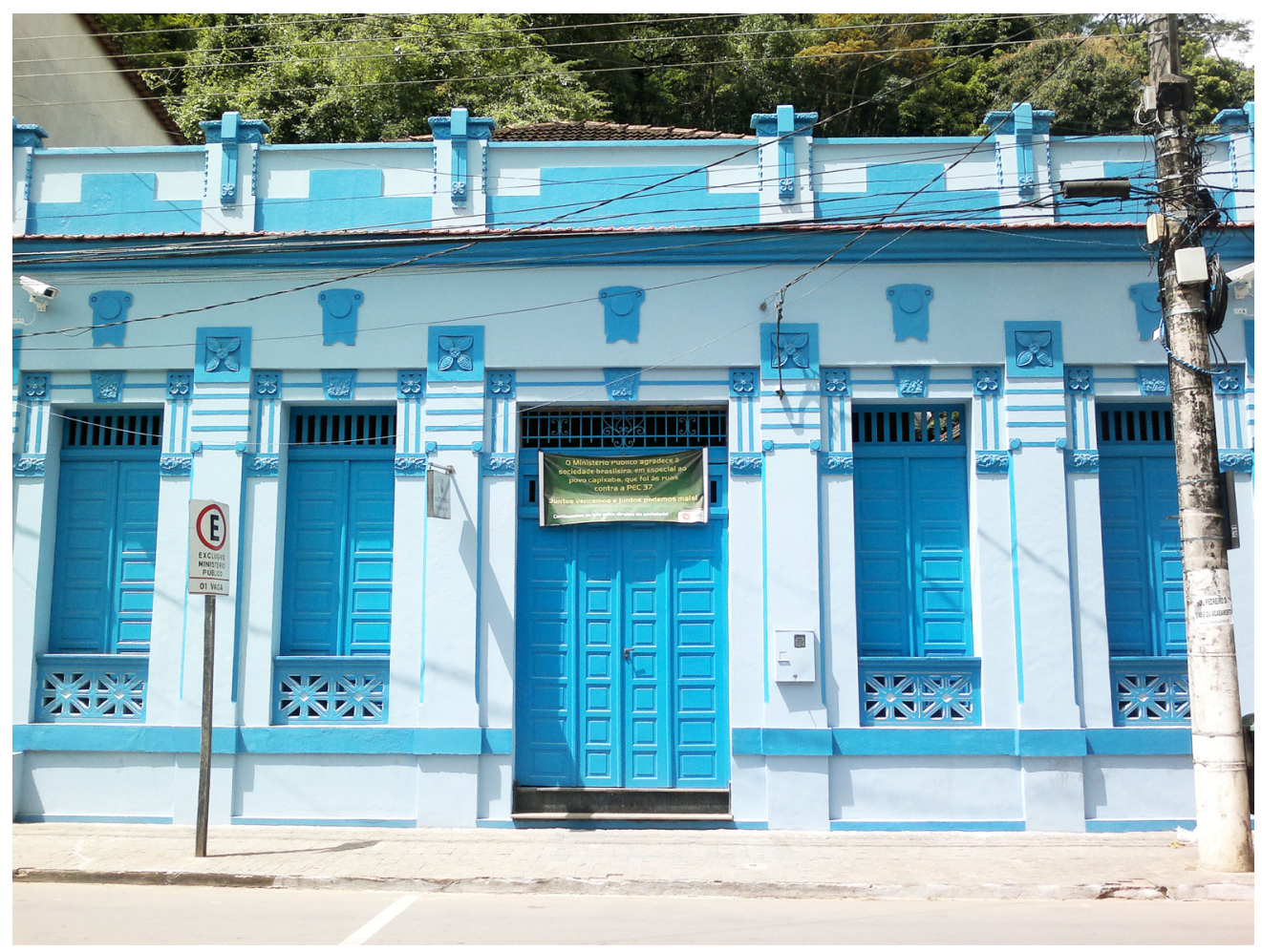

Figura 6 - Edificação em Santa Leopoldina, Espírito Santo, fotografia de 2017.

Visualiza-se a mesma questão na lgreja Matriz de Santo Antônio, no sítio histórico de Tiradentes, em Minas Gerais (Figura 7), pois a edificação setecentista apresenta uma textura homogênea nas cores da fachada, bem como exibe uma tonalidade de amarelo intenso nos cunhais, cornijas e ornatos. Outro exemplo desse paradigma pode ser visualizado no sobrado remanescente do período colonial brasileiro, localizado em Vitória, no Espírito Santo, tombado pelo Iphan e sede da Superintendência Estadual (Figura 8). A edificação passou por alterações ao longo dos séculos e apresenta hoje uma fachada em coloração verde e branca, de modo que o tom do verde é levemente saturado e brilhoso e tem textura bastante homogênea, assim como a cor branca, que não possui nenhuma aparência de antiga, nem em sua textura, nem em sua tonalidade. 
Figura 7 - Igreja Matriz de Santo Antônio, fotografia de 2017.

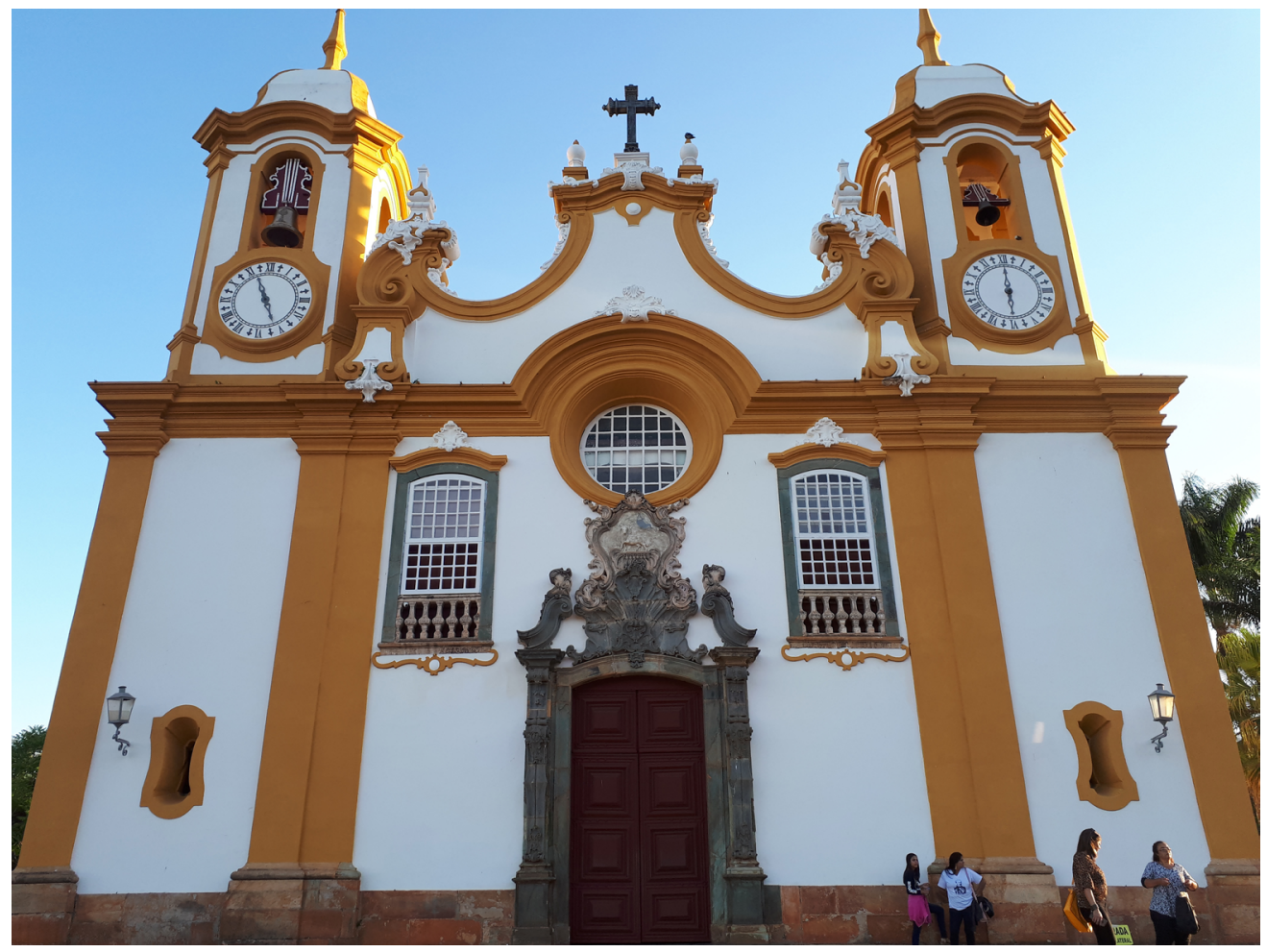

Figura 8 - Sede da Superintendência do Iphan no Espírito Santo, fotografia de 2019

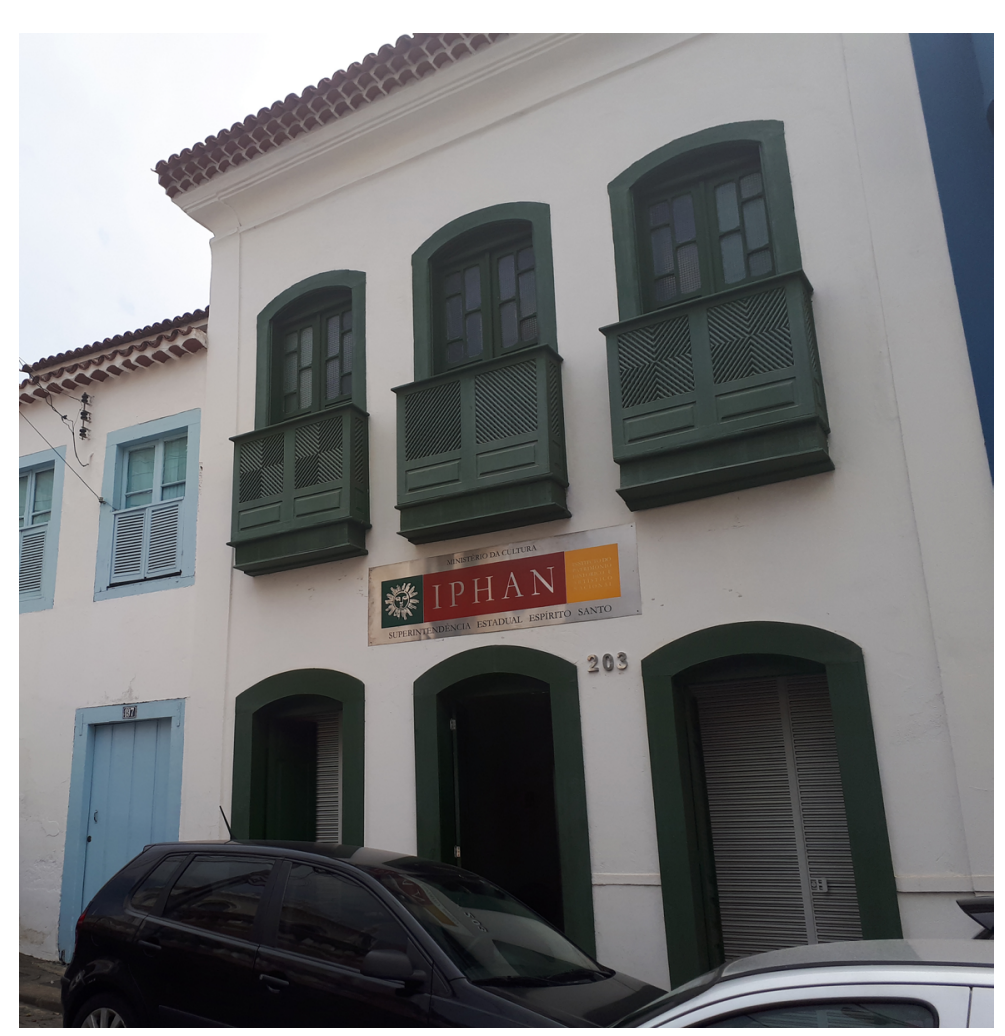


Podemos ainda visualizar a influência do paradigma do valor de novidade em diversas outras edificações de valor patrimonial, como no exemplo de um bem em Cachoeira do Sul, no Rio Grande do Sul, cuja fachada, única remanescente do edifício, encontra-se pintada em tom vermelho saturado e com aparência e textura incrivelmente novas (Figura 9). Ademais, podemos ver a ânsia do novo e da cor saturada em uma edificação na cidade de Campos dos Goyłacazes, na região norte do estado do Rio de Janeiro (Figura 10), um exemplo bastante significativo para se constatar o uso banal e midiático das cores das superfícies arquitetônicas, que passam a expressar uma logomarca comercial e, consequentemente, a destoar completamente de seus aspectos formais e compositivos.

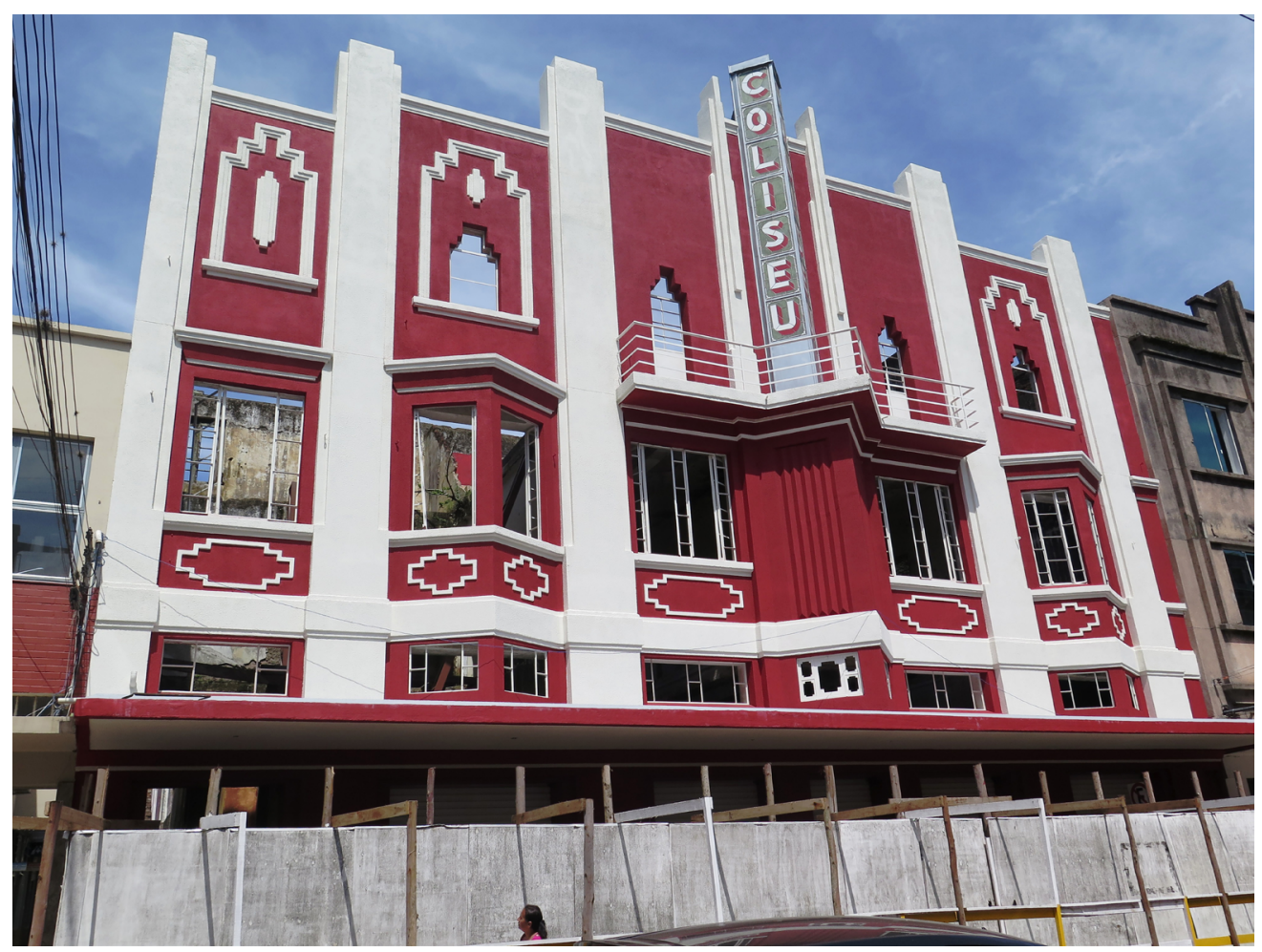

Figura 9 - Edificação em Cachoeira do Sul, Rio Grande do Sul. 


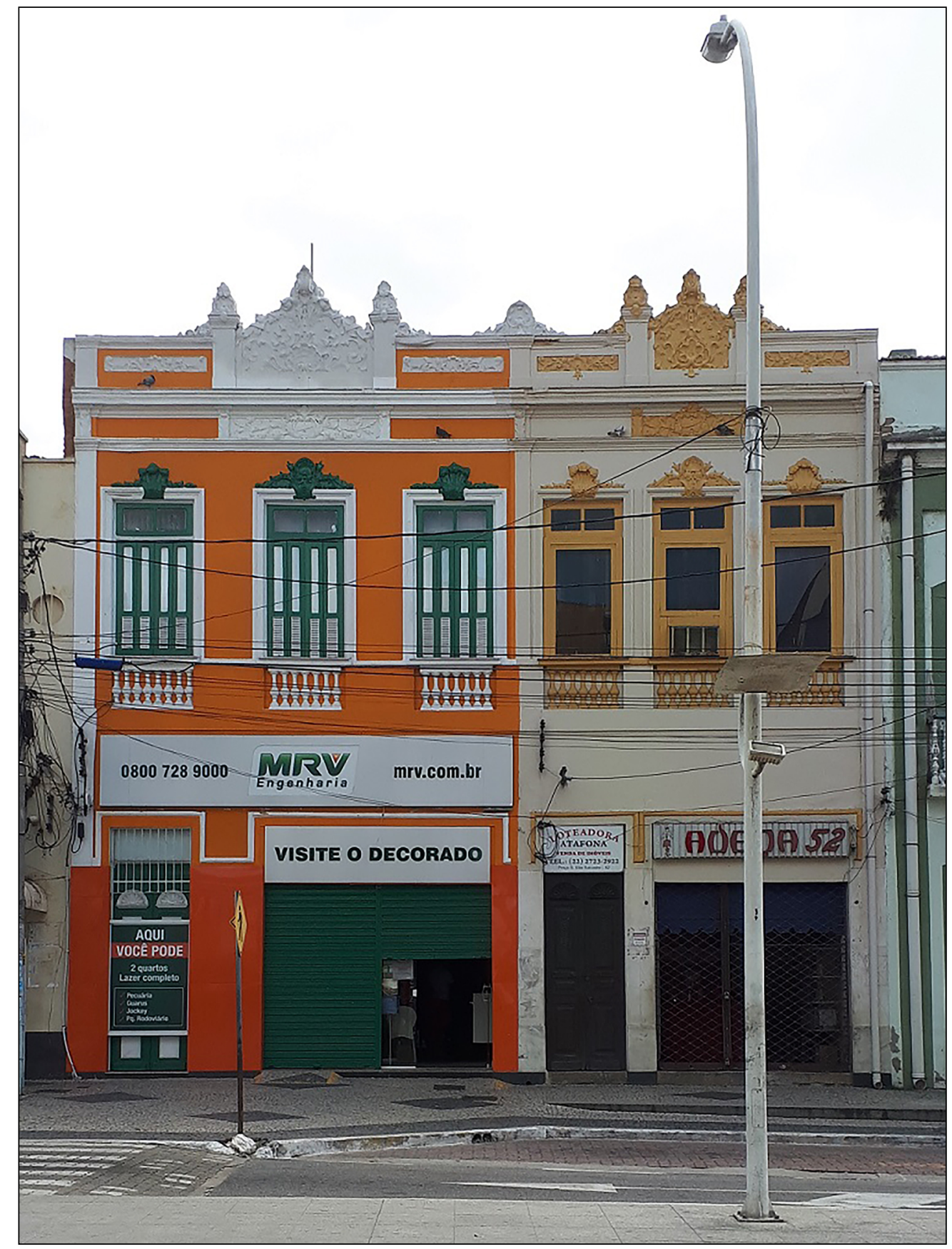

Figura 10 - Edificação em Campos dos Goyłacazes, Rio de Janeiro.

Diversos outros exemplos poderiam ser mencionados, pois a influência do paradigma do valor de novidade com o apelo imagético do novo e do rejuvenescimento forçado pode ser visualizado em várias cidades brasileiras, 
tanto nas capitais quanto nas regiões do interior do Brasil. Notadamente, a questão que emerge é a possibilidade de uma imagem e de uma identidade cromática cujos sinais do tempo sejam percebidos como a antiguidade de um lugar, e não como descaso ou negligência com o patrimônio cultural. Um aspecto fundamental do ato de restaurar é saber analisar a superfície não só do ponto de vista técnico e operativo, mas também em seus aspectos conceituais, segundo o entendimento de que há danos, pátinas e vestígios do tempo que não se configuram necessariamente como manifestações patológicas.

segundo dos paradigmas identificados constitui-se por meio da busca contemporânea por retratar uma imagem desejada sobre o passado através de uma paleta de cor muito específica, o que configura uma tendência cromática que se repete em diversas regiões a despeito da história do monumento ou do seu local. Hoje, identificamos essa tendência no uso do amarelo na arquitetura historicista. Ao utilizar esse termo, referimo-nos à arquitetura brasileira com traços neoclássicos e ecléticos. Trata-se, em realidade, da criação de uma narrativa fundamentada em um historicismo anacrônico, entendido no sentido do uso de formas históricas, como definiu Colquhoun ${ }^{102}$ ao discorrer sobre três interpretações para essa palavra. Para o autor, atualmente há um equívoco muito grande quando se utiliza o passado para criar modelos para o presente, o que ele qualifica como distorção ideológica, na medida em que a contemporaneidade (incluindo o modernismo) contempla atitudes distintas em relação à história dos séculos XVIII e XIX. $\bigcirc$ texto escrito em 1983 apresenta bases importantes para se entender as diferentes manifestações do historicismo, argumentando que uma atitude contemporânea compreende uma distância em relação a aspectos precisos dos estilos do passado, pois somente assim podem se tornar itens de consumo cultural. Note-se que Colquhoun ${ }^{103}$ argumenta a favor da tradição, pois a entende como condição para a produção de sentido e significado arquitetônico. Na realidade, Rocha-Peixoto ${ }^{104}$ esclarece a questão ao constatar que, embora o retorno ao passado não seja possível, o esforço historicista de buscar recompor o passado produz uma imagem que é real somente como imagem. Isto é, a história é sempre uma narrativa e não uma compilação de dados e fatos e, dessa forma, os bens culturais constituem uma imagem do passado que é construída pelo presente e que abrange a interpretação que os homens do próprio presente fazem desse passado.

Assim, no âmbito cromático, um exemplo bastante característico desse processo e muito presente em intervenções cromáticas na atualidade no Brasil trata-se da utilização da coloração amarela saturada para revestir bens edificados que apresentam arquitetura eclética ou até mesmo neoclássica. Em 
muitos casos a edificação não foi pintada com essa cor ao longo da sua trajetória e optou-se por essa tonalidade somente no século XXI. Trata-se, portanto, de uma nova interpretação e narrativa criada ao se buscar estabelecer uma repetição desse padrão cromático. Note-se que não estamos determinando um juízo de valor, mas acreditamos que, para o arquiteto e urbanista imerso no modo culturalista, o que importa, efetivamente, não é uma apropriação clássica ou tampouco uma erudição sobre o passado, e sim uma capacidade refletida em atitudes concretas e práticas para articular o repertório arquitetônico com a cidade contemporânea de maneira consciente. ${ }^{105}$

Dando continuidade aos exemplos, em Vitória, no Espírito Santo, a cor amarela reveste a grande maioria dos bens tombados pelo Conselho Estadual de Cultura localizados no centro da cidade. Entre eles, destaca-se o Palácio Anchieta e o Palácio da cultura Sônia Cabral - este último localizado em frente à fachada lateral do primeiro (Figura 11) -, a Escola Maria Ortiz, o viaduto Caramuru, a escadaria Maria Ortiz, o museu de Arte, o além do já citado Teatro Carlos Gomes.
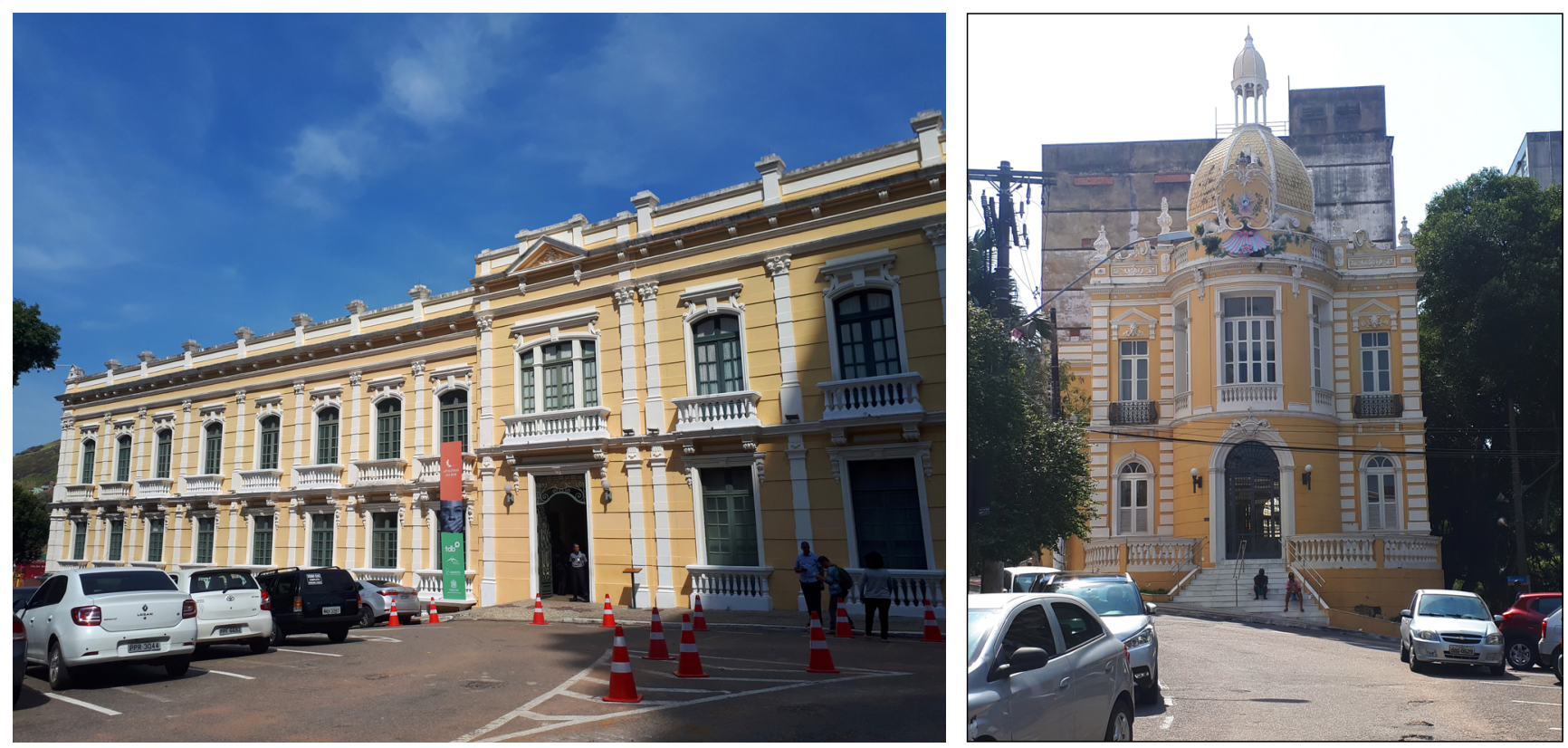

Figura 11 - Palácio Anchieta (à esquerda) e Palácio Sônia Cabral (à direita), fołografias de 2019 
Situação análoga é encontrada no estado de São Paulo, onde podemos constatar o mesmo amarelo com intensa saturação nas fachadas da Catedral Metropolitana de Campinas (Figura 12), inclusive a despeito dos ornatos nos cunhais e capitéis que passam despercebidos com esta composição monocromática.

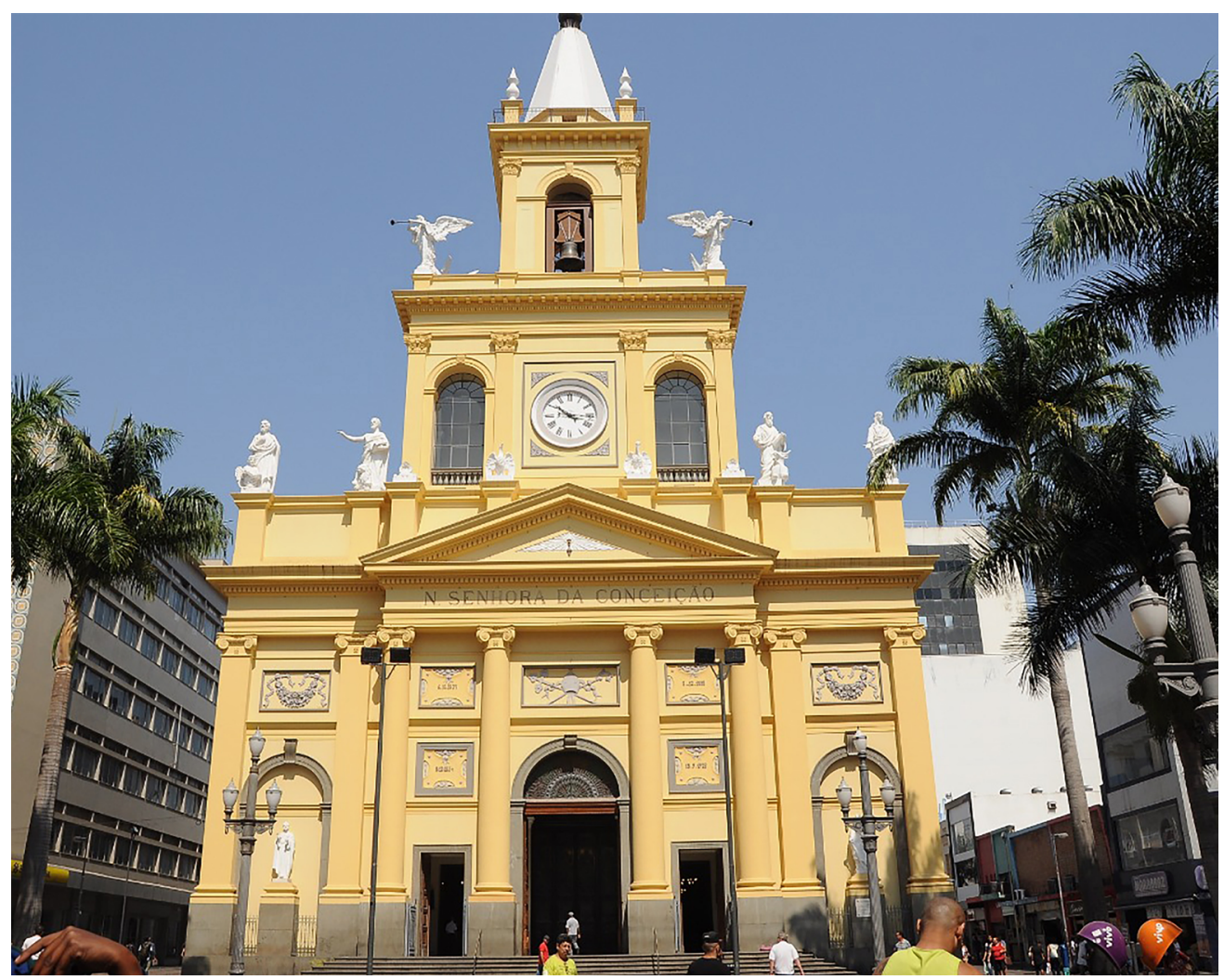

Figura 12 - Catedral Metropolitana de Campinas. Fonte: <https://bit.ly/2XExWdD>.

Também verificamos a coloração amarela na Estação da Luz, uma importante estação ferroviária localizada na cidade de São Paulo (Figura 13). Podemos ainda citar o monumento Château d'Eau, situado na cidade de Cachoeira do Sul, no estado do Rio Grande do Sul, que se encontra atualmente pintado com a mesma coloração única de amarelo saturado em todas as suas superfícies arquitetônicas (Figura 14). 
Figura 13 - Estação da Luz, em São Paulo, fotografia de 2019.
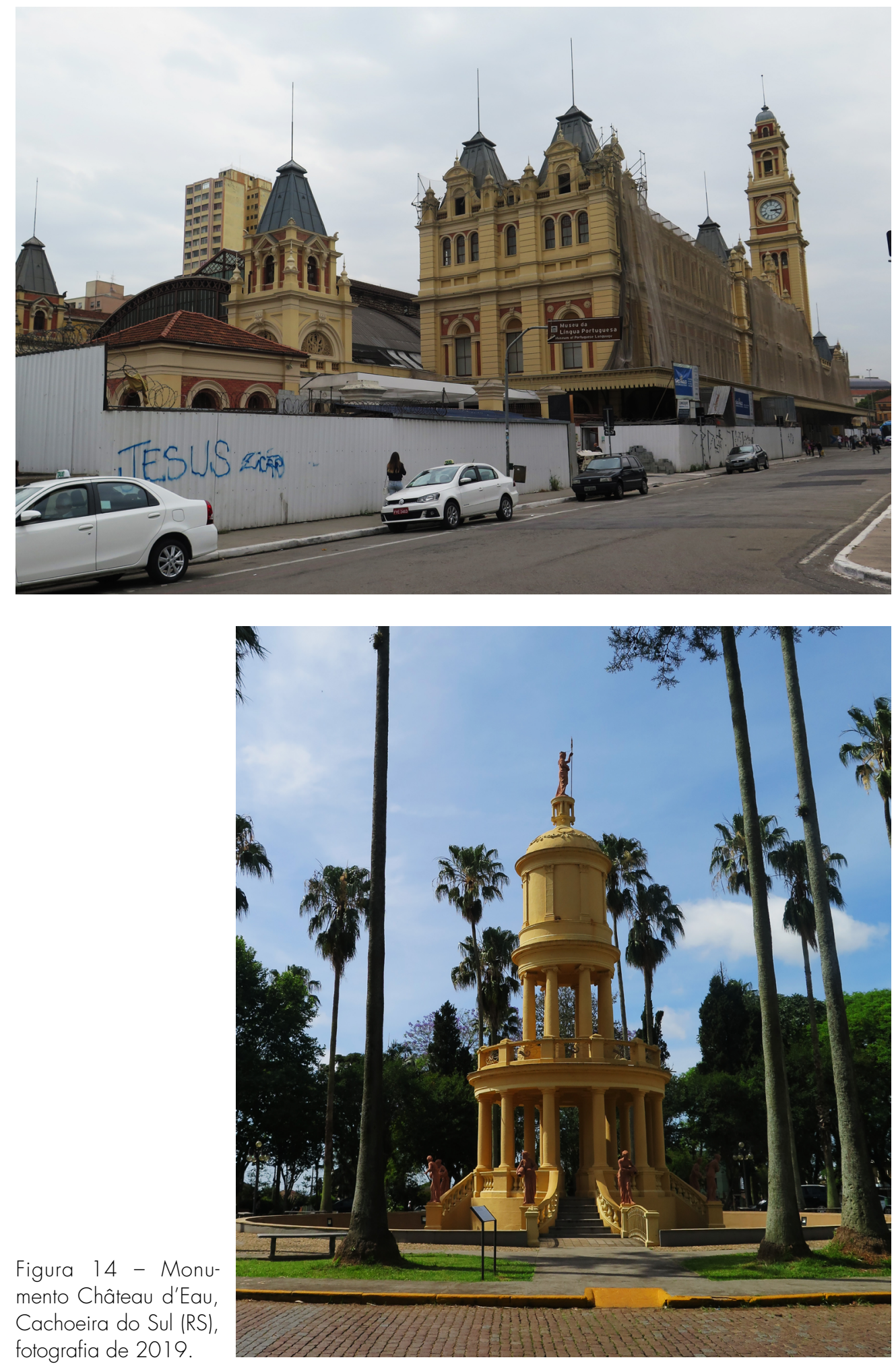
Também se pode visualizar a abrangência desse paradigma na Catedral Metropolitana de Florianópolis, em Santa Catarina, que apresenta, assim como os demais exemplos aqui demonstrados, a cor amarela em suas superfícies arquitetônicas (Figura 15).

\section{(3)}

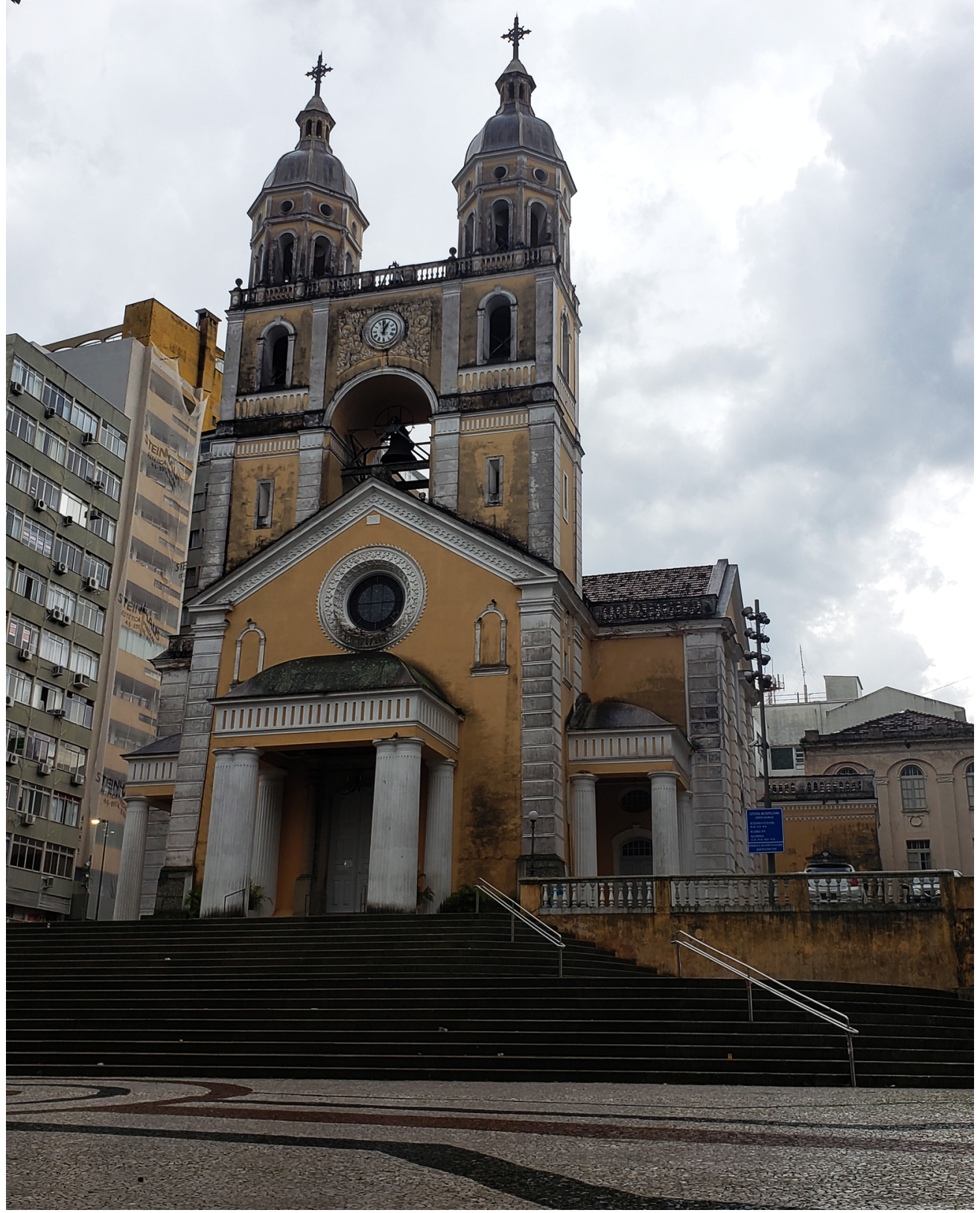

Figura 15 - Catedral Metropolitana de Florianópolis (SC), fotografia de 2020. 
amarelo é tão emblemático na contemporaneidade dos monumentos brasileiros, que a arquiteta e pesquisadora Regina Tirello salientou em um artigo, publicado pela Unesp em 2009, que "restaurar não é pintar os edifícios de amarelo". ${ }^{106}$ Por outro lado, é oportuno ressaltar outras situações emblemáticas em que se constata a influência de uma tendência cromática baseada em uma espécie de historicismo anacrônico no Brasil, o qual troca o paradigma da cor amarela pela coloração branca, em uma narrativa mítica para simular uma suposta imagem colonial. Já se argumentou que essa busca não tem como objetivo recompor de maneira precisa um passado, mas se aproxima, na realidade, de uma abordagem do passado enquanto mito voltada a alimentar o consumo cultural.

Nesse cenário, podemos visualizar edificações erguidas durante o período colonial às quais foram impostas transformações ao longo de sua trajetória temporal e cujos ornatos não são levados em consideração ao se projetar a cor que o bem apresentará na contemporaneidade. Para criar uma imagem, utiliza-se a cor branca nas superfícies arquitetônicas de forma a reproduzir a cal, embora sem a textura característica desse revestimento, ignorando a relação de figura-fundo dos elementos arquitetônicos da edificação, como no exemplo do Convento do Carmo, localizado na cidade de Cachoeira, na Bahia (Figura 16), que em sua última restauração teve suas superfícies arquitetônicas alteradas da cor azul e da cor branca lque marcava os ornamentos e demais componentes compositivos) para a cor branca em todos os elementos arquitetônicos, o que impossibilita a visualização, por exemplo, do trabalho decorativo nas cornijas ou acima das volutas da porta de entrada. 


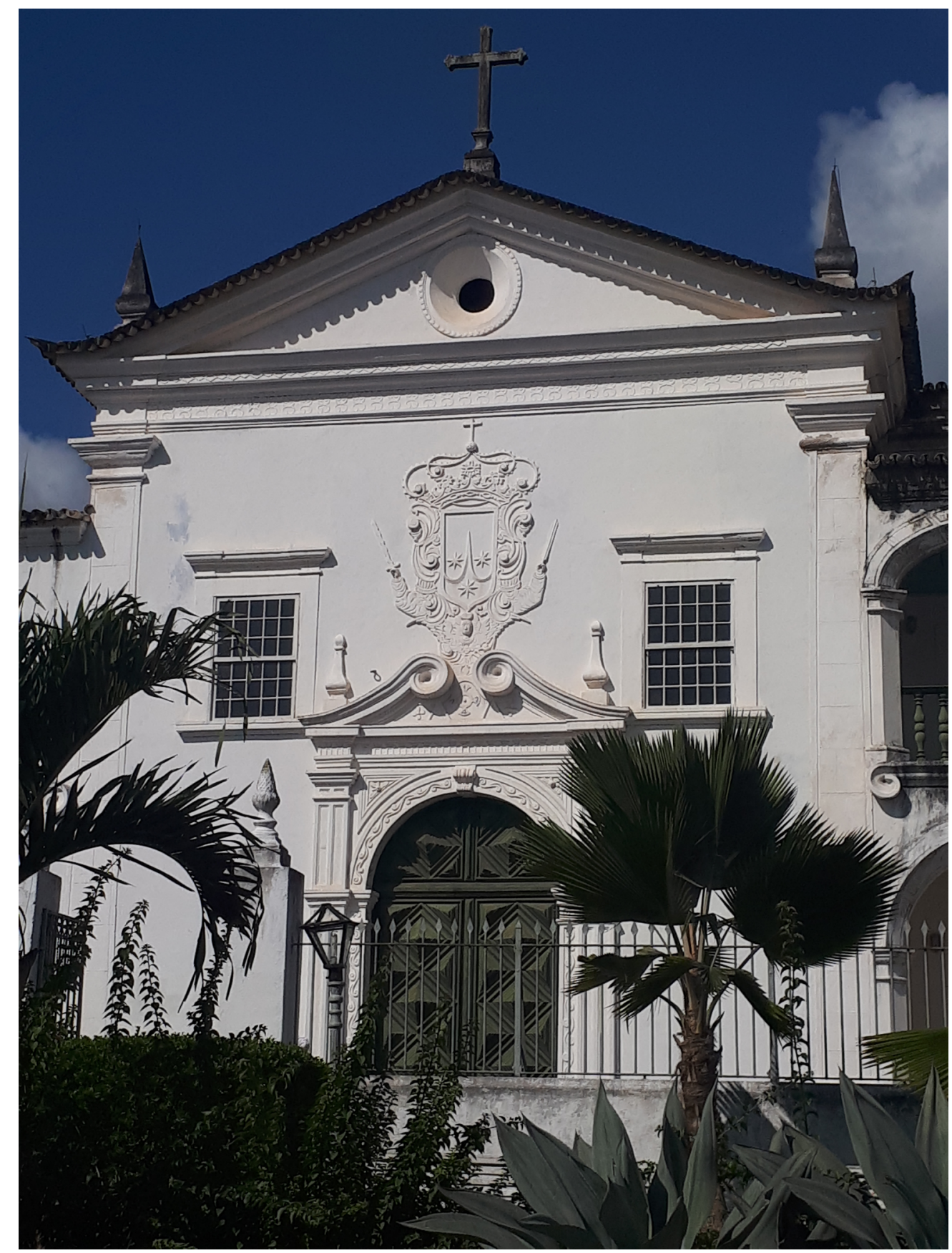

Figura 16 - Convento do Carmo, cidade de Cachoeira (BA), fotografia de 2019.

Esse processo se alarga e culmina no paradigma do turismo cultural, com a criação de uma imagem de cidade histórica adequada enquanto item de consumo. Assim, o terceiro paradigma contemporâneo configura-se na imposição 
do turismo cultural, de modo que esse paradigma estrutura muitas intervenções cromáticas em áreas urbanas, especialmente as que estão entre os destinos mais procurados pelos turistas. Trata-se da criação de uma narrativa que tenta forjar a imagem de um passado que o turismo cultural contemporâneo definiu. Essa imagem passa a ser replicada indiscriminadamente em todo o território brasileiro e, assim, realiza-se uma homogeneização dos núcleos urbanos. Dessa forma, verifica-se a relação cromática definida por esse paradigma: a arquitetura eclética e até mesmo neoclássica devem ser pintadas com cores vibrantes (de uma paleta seletiva) e apresentar ornatos brancos, enquanto a arquitetura colonial deve ser toda branca, com a superfície mural bem homogênea, e apresentar tons coloridos (também de uma paleta seletiva) nas esquadrias, portas e em acréscimos como calhas, como no exemplo da cidade de Tiradentes, em Minas Gerais (Figura 17).

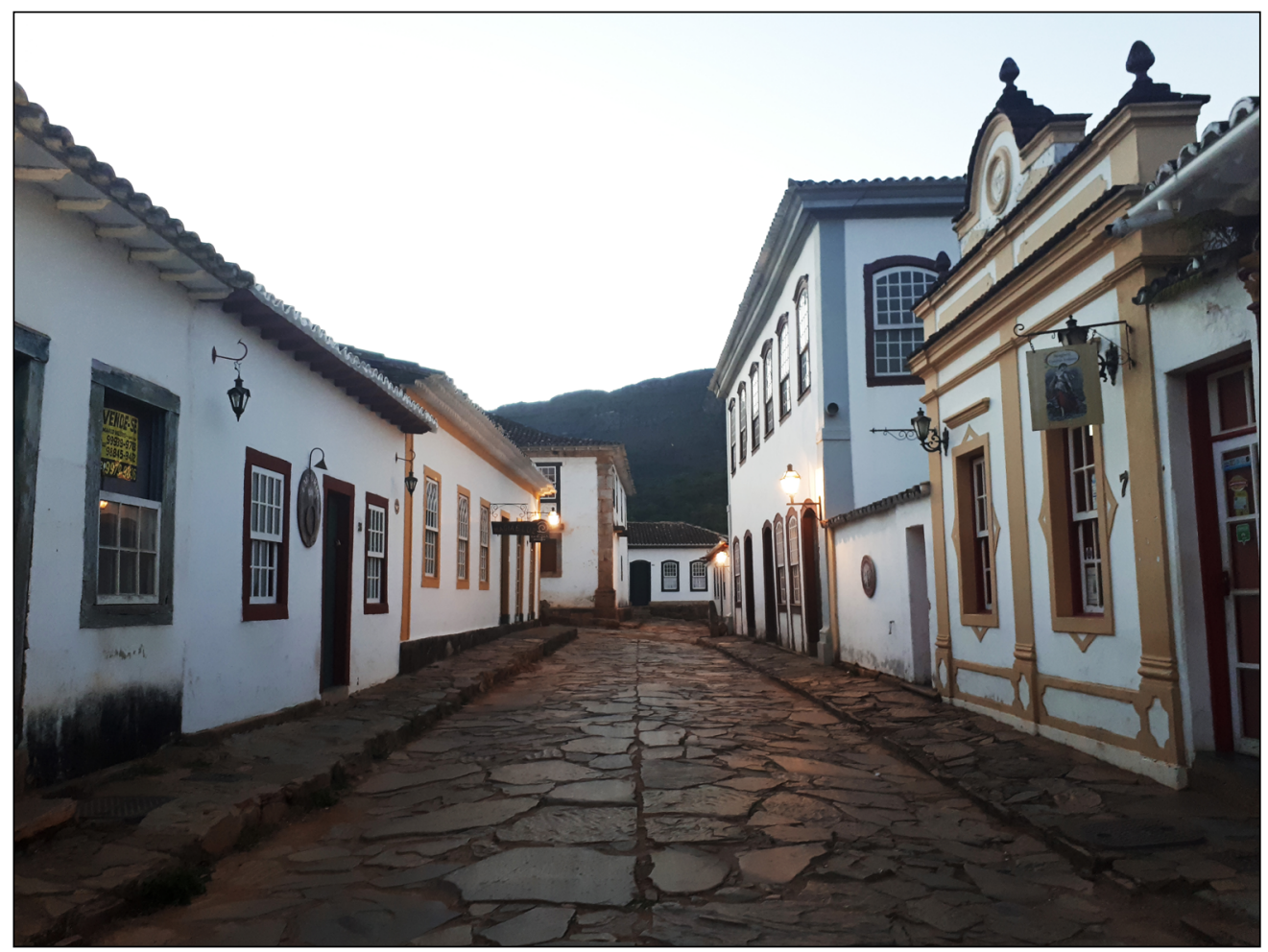

Figura 17 - Sítio histórico de Tiradentes (MG), fotografia de 2019.

Na fundamentação desse paradigma está a globalização e sua dinâmica, em que o turismo é a primeira indústria mundial, entendida como uma atividade que impera em "um mundo autodefinido por dois conceitos-tipo antagônicos: globalização e sustentabilidade, que possivelmente seriam dois dos tipos ideais que, seguindo a conceitualização de Max Weber, caracterizariam as tendências 
de nossa época". ${ }^{107}$ No entanto, para o autor, a globalização essencialmente neoliberal é antagônica ao objetivo da sustentabilidade, pois quando uma cidade é reconhecida em suas particularidades locais, há um investimento, e quanto mais ela se destaca no panorama global em razão de sua diversidade cultural, mais se aproxima da homogeneização e do turismo de massa. Com esse processo, a cidade acaba enfraquecendo ou mesmo perdendo os atributos e a diversidade cultural que a levaram a ser local de interesse patrimonial. Esse é o lado perverso de um fenômeno complexo como o turismo, pelo qual é possível perceber as contradições da própria sociedade, a exemplo das tensões entre cultura e consumo, ou homogeneização e perpetuação da memória.

Tais argumentos devem ser entendidos em toda sua complexidade, iá que o turismo é uma "experiência essencial do ser moderno". 108 De fato, ao analisarmos a relação do turismo com o patrimônio cultural, é necessário observar o fenômeno de maneira abrangente, pois se por um lado ele pode se sobrepor às estruturas existentes de maneira prejudicial, quando se configura como um turismo de massa, por outro lado, ele permite visibilidade, explora possibilidades de valorização do patrimônio cultural e pode ser trabalhado como uma oportunidade positiva para muitos tecidos urbanos de valor patrimonial. Assim, esse binômio complexo deve ser intensamente estudado, pois na pós-modernidade não há como ignorar as atividades turísticas. É necessário, portanto, buscar alternativas para que elas sejam efetuadas de maneira positiva, senão continuaremos a reproduzir cenários globalizados, com esvaziamento da memória local para que sejam substituídas por imagens com uma narrativa fundamentada apenas no consumo.

Cabe ressaltar que os regulamentos internacionais que abordam o tema do turismo cultural são amplos, incluindo recomendações e cartas publicadas pela Organização Mundial do Turismo (OMT), pela Organização das Nações Unidas para a Educação, a Ciência e a Cultura (Unesco) e pelo Conselho Internacional de Monumentos e Sítios (lcomos), entre outras instituições que buscam formular orientações para a atividade turística dentro dos tecidos históricos. ${ }^{109}$ A própria carta do Icomos de Turismo cultural publicada em 1976 e depois revisada em 1999, preconiza seis princípios que buscam destacar as atividades turísticas como meio de colaboração intercultural realizado com a participação das comunidades locais. ${ }^{110}$ Entretanto, nota-se que em várias intervenções no patrimônio edificado em núcleos urbanos brasileiros prevalece uma narrativa imagética que esvazia os significados das relações de identificação que antes existiam naquele território, ignorando, assim, a noção de interpretação do patrimônio cultural como palimpsesto, segundo a qual a história é um processo de estratificação.
107. Montaner e Muxí (2014, p. 143).

108. Ibid., p. 143 .

109. Yañes (2019).

110. Ibid. 
111. Lenclos e Lenclos, op. cit.

112. Ibid.
No âmbito cromático, para ilustrar esse paradigma, reforçamos a constatação de Lenclos e Lenclos ${ }^{11}$ que discorre sobre a transformação do Pelourinho, em Salvador, no final da década de 1990, quando a área passou a integrar intensa atividade turística. Nesta intervenção, houve uma mudança nas cores das fachadas e outras alterações de forma e, de acordo com o autor, especialmente na área restaurada da região, as fachadas passaram a ter cores limitadas a uma paleta seletiva, com os caixilhos das janelas e das portas centrais geralmente brancos, às vezes beges. Com certo pesar, o autor destaca que bairros antigos, mas não restaurados, exibiam uma variedade maior de tonalidades, com portas em tons de azul e ocre médios, bem como cinzas e verdes suaves. Da mesma maneira, Lenclos e Lenclos, ${ }^{112}$ quando analisa as cores no meio urbano, destaca que a ocupação do solo com as casas geminadas cria ritmos no espaço urbano com as cores vivas e contrastantes. $\bigcirc$ autor cita como exemplo a cidade de Cachoeira, na Bahia, onde as fachadas, os ornamentos e as esquadrias coloridos afirmavam sua identidade em paletas personalizadas (Figura 18). No entanto, atualmente, pode-se verificar que as edificações históricas de Cachoeira apresentam quase todos os ornamentos na cor branca e existem algumas esquadrias coloridas, em tons selecionados de azul e verde ou cinza (Figura 19).

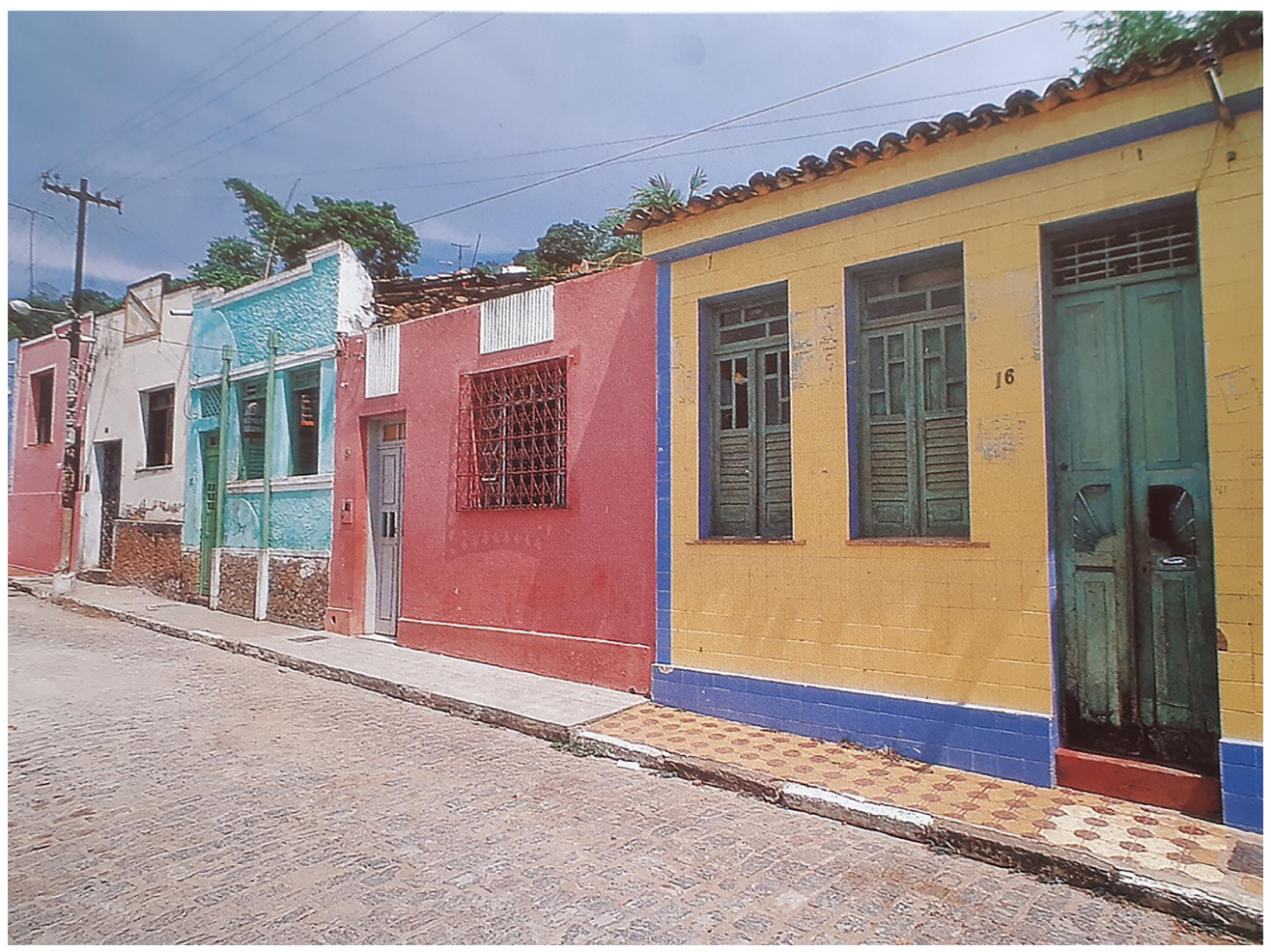

Figura 18 - Cidade de Cachoeira, na Bahia, na década de 1990, onde se verificava cores vivas nas alvenarias e nos ornatos das fachadas. Fonte: Lenclos e Lenclos, 2004, p. 115. 


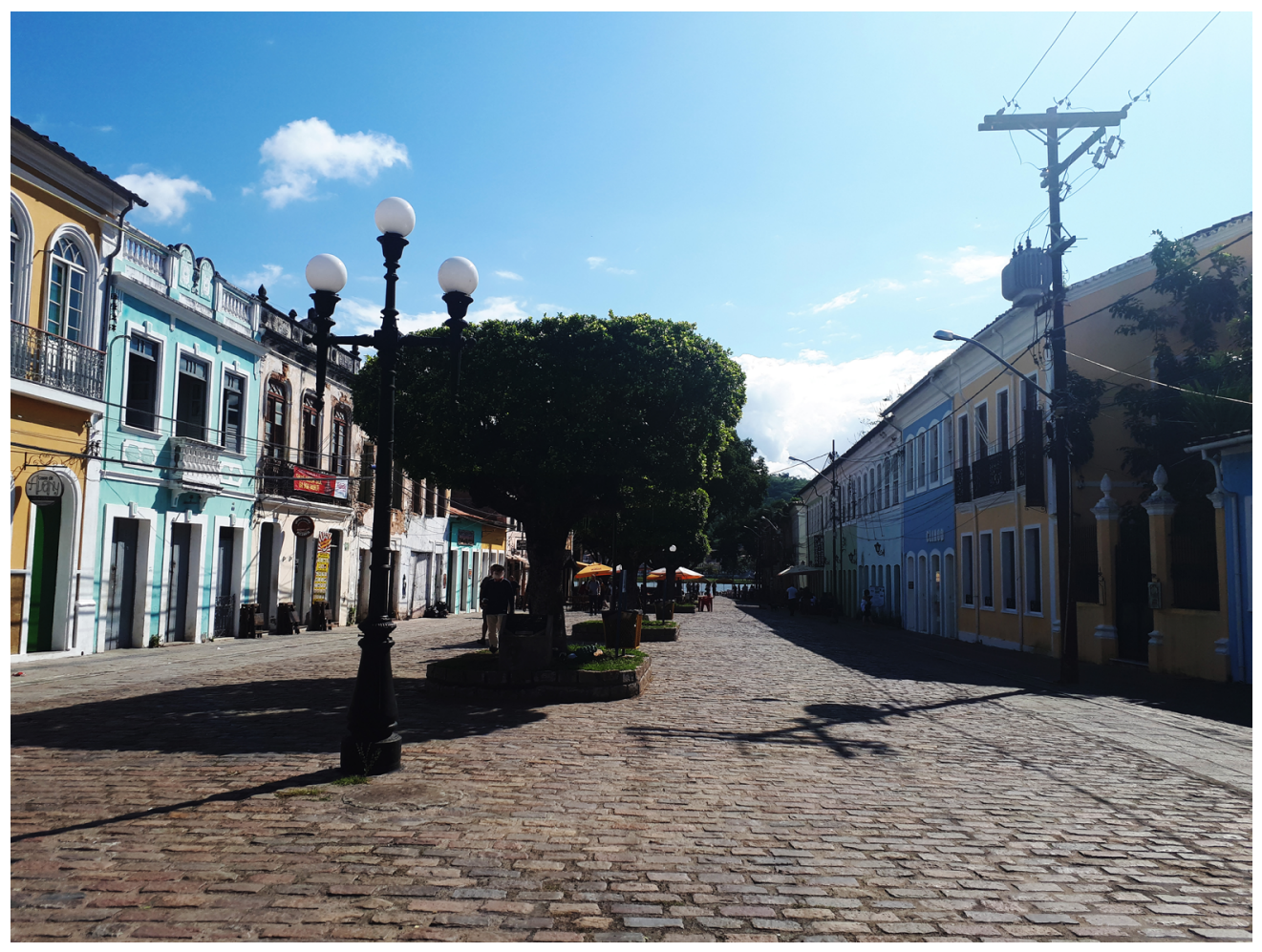

Figura 19 - A cidade de Cachoeira em setembro de 2019, onde se verifica que as fachadas apresentam tons pastéis e as esquadrias e ornatos são predominantemente brancos.

Ao apontar tais considerações, é válido salientar intervenções cromáticas constatadas em outros países, onde se verifica que o tratamento dado à superfície arquitetônica é mais coerente com um processo histórico-crítico, pois prevalece a materialidade heterogênea da argamassa e mantém-se as marcas do tempo mesmo em situações em que o bem está em pleno uso, como nos exemplos das Figuras 20 e 21, edificações localizadas na cidade de Colônia do Sacramento, no Uruguai. Note-se que não se trata de ignorar manifestações patológicas, pois os revestimentos do bem aparentemente estão conservados e íntegros. A edificação revela apenas um olhar diferente para a policromia, segundo o qual não se busca rejuvenescer o patrimônio edificado por meio de suas cores, tampouco reproduzir cores intensas em um contexto que não tem relação com uma paleta saturada. 
Figura 20 - Edificação em Colônia do Sacramento, Uruguai, onde funciona um restaurante, fotografia de 2019

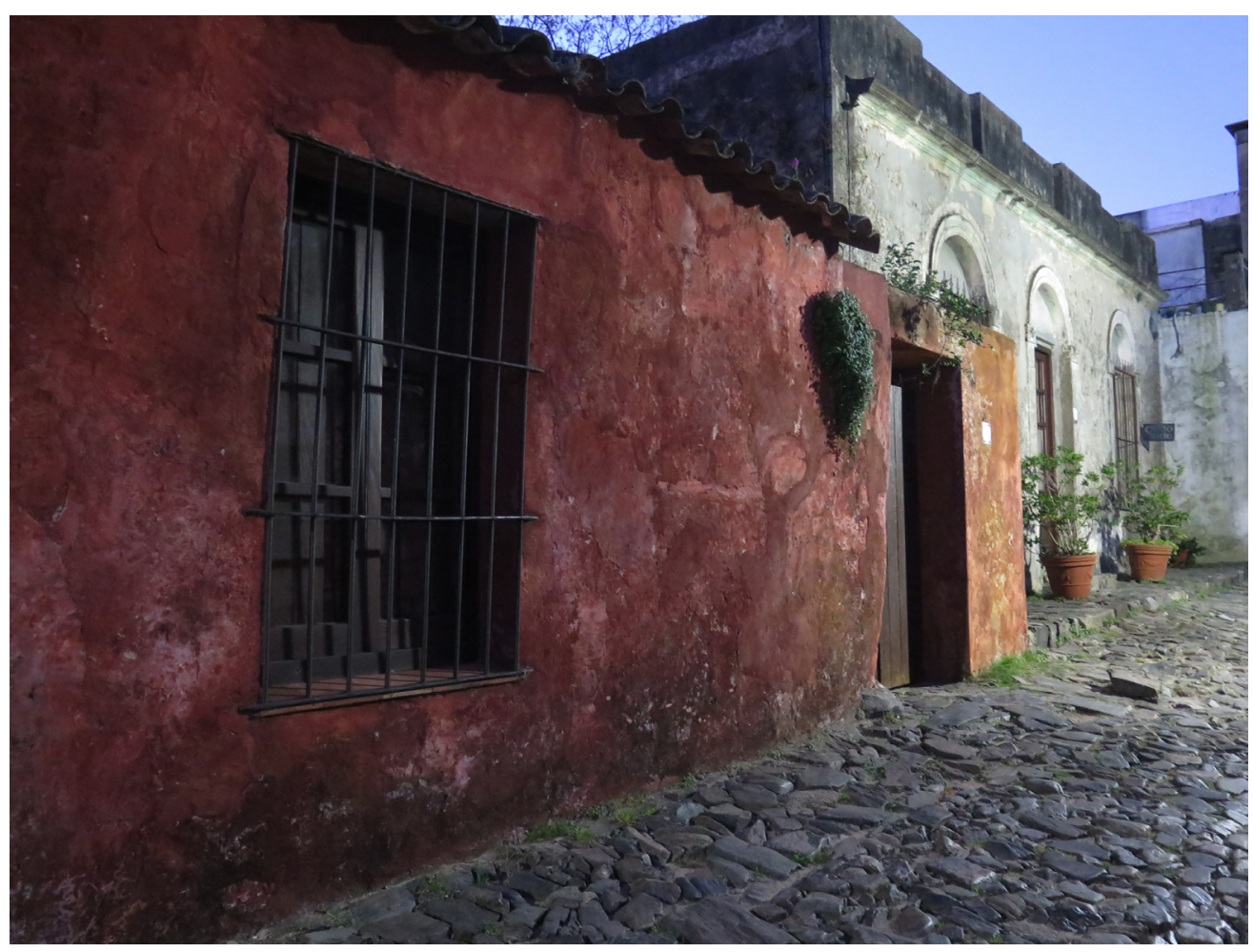

Figura 21 - Edificação em Colônia do Sacramento, Uruguai, onde funciona um restaurante, 2019

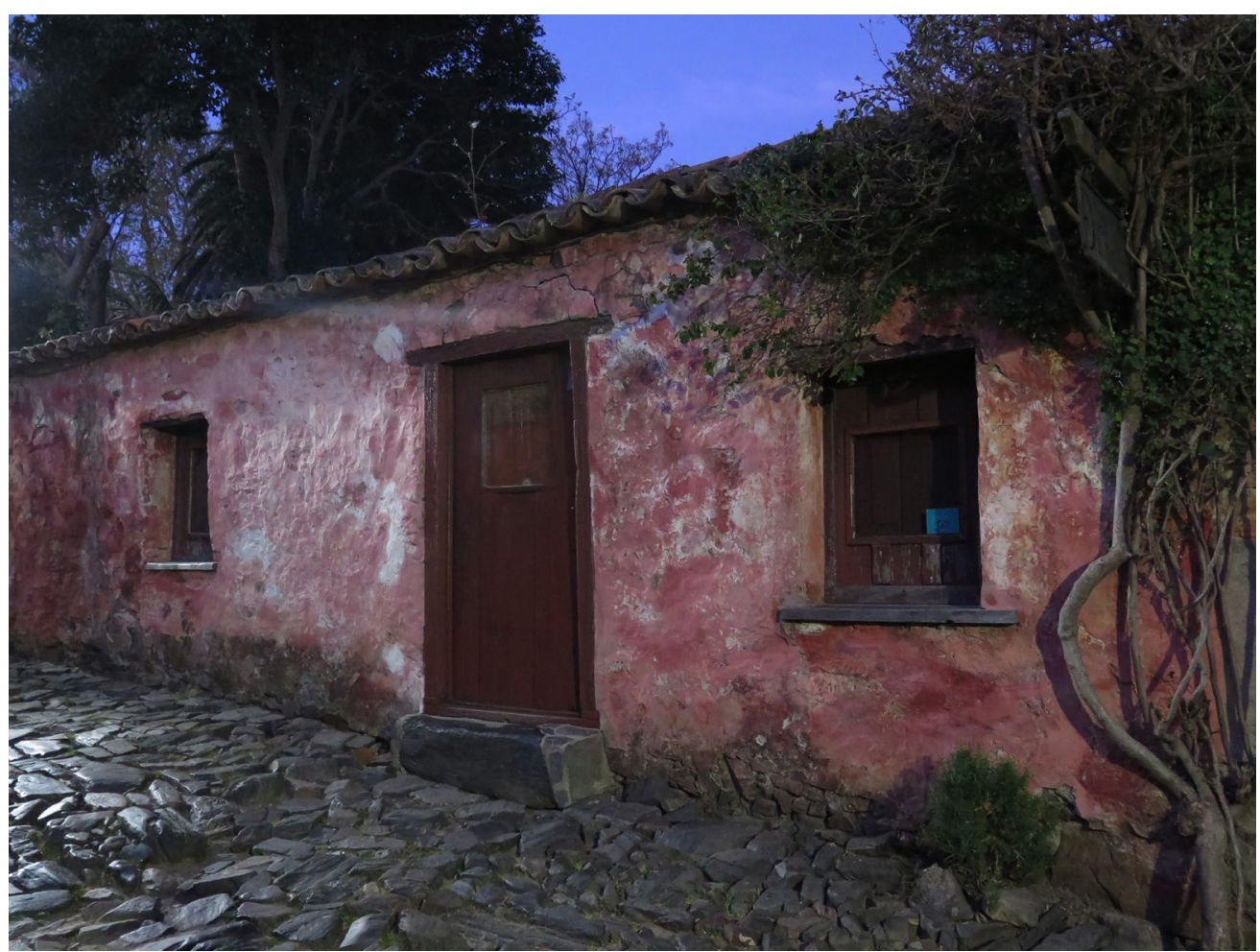


Sem ignorar que tais exemplos não se inserem no contexto do Brasil, reforçamos a necessidade de, com uma forte base teórica, vislumbrar planos de 114. Ibid., p. 51. conservação para o patrimônio cultural brasileiro que sejam coerentes com a história e a cultura de cada local, superando a lógica capital ista e a reprodução de imagens desconectadas dos valores territoriais. Pode-se afirmar que, no Brasil, a superficialidade consumista dos signos e das imagens afetou a preservação do patrimônio cultural tanto quanto as intempéries podem ser nocivas para sua integridade física. Esse processo iniciou-se nas últimas décadas do século XX, como pontua Sant'anna ${ }^{113}$ ao analisar o que denominou de "cidade-atração" nos sítios históricos brasileiros. O autor observa que, concomitantemente a esse fenômeno, há um consenso entre diversos autores acerca da emergência de um novo estágio do capitalismo na década de 1970. Esse novo estágio é baseado em uma nova economia globalizada, em que a estrutura e a lógica de funcionamento enfraquecem os poderes e controles dos Estados nacionais sobre seus processos econômicos, sociais e culturais. Paralelamente, ocorre um crescimento do turismo cultural, de modo que cultura e patrimônio tornamse aspectos que valorizam as cidades. Nesse sentido, a autora afirma que:

A competição interurbana por capitais e atividades, o crescimento do turismo cultural e a crescente preferência das elites gerenciais por áreas históricas deflagraram um fenômeno de construção, mudança ou reforço de imagens urbanas com base em materiais fornecidos pela cultura e pelo patrimônio, bem como o aumento, nos países centrais, de valor comercial de imóveis localizados em setores e bairros antigos. ${ }^{114}$

A autora ainda sinaliza que a expansão do campo da cultura, associada ao processo decorrente de transformação dos bens culturais em produtos de consumo, reduziu os limites entre cultura superior e cultura de massa. Nesse panorama, o uso do patrimônio como investimento atrativo demanda estratégias variadas para o tornar rentável e, como na sociedade contemporânea a aparência visual ocupa um lugar central na atenção dos indivíduos, "há um razoável consenso entre os teóricos quanto à importância do 'visual' e da imagem na cultura contemporânea". ${ }^{115}$

É, portanto, inegável a importância da imagem urbana e, ao traçar caminhos possíveis - que sejam construídos a partir da estreita interação entre teoria e prática e que fujam da sedução do mito da imagem e da lógica capitalista de consumo cultural -, vislumbramos a criação de uma ferramenta de leitura cromática, acompanhada de uma interpretação do contexto urbano que articule edifício e cidade, de maneira a pensar num restauro que compreenda a totalidade complexa do fenômeno urbano do patrimônio edificado. Uma ferramenta conceitual dessa complexidade e abrangência tem sido defendida por Vitiello, ${ }^{116}$ que preconiza a diversidade tanto de aspectos 
117. Aguiar, op. cit.

118. Vitiello (2011, p. 608, tradução nossa). figurativos quanto perceptivos que caracterizam o meio urbano, reforçando o papel da cor como elemento essencial para a compreensão e vivência urbana.

Note-se que uma ferramenta como essa não se trata de um plano de cor como os que foram utilizados na Europa a partir da década de 1980, ${ }^{117}$ pois englobaria uma multiplicidade de fatores que os planos de cor ainda não conseguiram abranger. Essa nova ferramenta, na realidade, aproxima-se do que chamamos de práxis da conservação, pois teria o foco metodológico de um plano de conservação, que inclui uma extensa análise histórica tanto documental quanto iconográfica sobre o tema das cores, além de outras análises de componentes em diversas escalas e de processos de transformação já ocorridos, de forma a viabilizar a proteção da preexistência, bem como prever um planejamento de transformações. Ao discorrer sobre essa ferramenta, Vitiello argumenta:

\begin{abstract}
Portanto, poderia ser uma ferramenta operacional para conter estudos e procedimentos abrangendo todos os aspectos da preservação do histórico reservatório urbano. As análises de todos aqueles componentes que, em diferentes escalas, estão interligados com o tema da cor nos edifícios que compõem a cidade e a tornam um organismo vivo, podem encontrar seu devido lugar dentro dela. Tal ferramenta de planejamento deve ser capaz de permitir a proteção do existente através de um planejamento de transformações, implementado a partir do que hoje representa um espaço, do que foi e do que progressivamente queremos que se torne. ${ }^{118}$
\end{abstract}

Reforçamos que essa ferramenta não destoa muito do entendimento segundo o qual há necessidade de identificar os valores territoriais em uma escala ampla, histórica e fenomenológica. Portanto, a centralidade de uma ferramenta de leitura e interpretação cromática reside na história enquanto um processo de estratificação, com muitas camadas que representam o tempo e as particularidades do território.

\section{CONSIDERAÇÕES FINAIS}

A reflexão deste artigo busca contribuir para a construção teórica nacional acerca do problema das cores das superfícies arquitetônicas do patrimônio cultural, entendendo-o como uma questão de relevância tanto arquitetônica quanto urbana no âmbito dos bens culturais edificados. No Brasil, nas últimas décadas ocorreram importantes avanços na área da ciência da conservação a partir da tecnologia do restauro, com trabalhos significativos sobre a caracterização física, química e mineralógica dos pigmentos e revestimentos das superfícies arquitetônicas. Esse 
avanço técnico foi acompanhado de avanços conceituais sobre a cor enquanto elemento determinante do projeto de restauro, mas eles não foram efetivamente incorporados nas intervenções cromáticas, nas quais é possível visualizar a reprodução de modelos voltados para o consumo cultural.

Assim, o objetivo amplo deste artigo é contribuir para o debate atual por meio de uma síntese crítica de ideias e visualização de exemplos práticos, com destaque à necessidade de um aprofundamento teórico nas decisões projetuais acerca da cor no patrimônio cultural edificado. Os argumentos aqui defendidos objetivam revelar os paradigmas que estruturam as intervenções cromáticas nos bens edificados, que, embora não sejam assumidos enquanto dogmas, são traduzidos em decisões cromáticas nas intervenções nos bens culturais.

Em escala ampliada, buscou-se discorrer sobre a cor das superfícies arquitetônicas também em seus significados histórico, político, social e cultural, com o intuito de conceber a leitura estética do sítio enquanto imagem figurada. Dessa forma, os argumentos aqui explorados pretendem demonstrar que os revestimentos e as cores da arquitetura têm objetivos para além de sua proteção física. São documentos históricos e artísticos e devem, por meio de soluções estéticas, garantir o entendimento da linguagem arquitetônica do patrimônio edificado.

Por outro lado, diante dos paradigmas identificados nas cores do patrimônio edificado, cabe reforçar que o objetivo deste artigo não é criticar indiscriminadamente todas as intervenções cromáticas da contemporaneidade brasileira, mas sim destacar que elas não estão alinhadas ao discurso do restauro crítico e à particularidade de cada caso e de cada contexto; tampouco demonstram abranger os valores territoriais e a relação das cores com o lugar. Sabe-se, por outro lado, que qualquer intervenção em bens culturais, inclusive no âmbito cromático, deve ser fundamentada com forte embasamento teórico e princípios bem definidos. Embora haja, naturalmente, a particularidade de cada situação, qualquer solução adotada deve ser alicerçada em princípios teóricos consolidados. Sobre essa questão, Kühl119 discorreu acerca da pluralidade de caminhos e orientações dentro da teoria, observando que há aproximações que delimitam o campo, as quais, ainda que de maneira ampla, viabilizam estabelecer diretrizes adequadas à restauração. Trata-se de uma questão de extrema importância, pois o restauro é um campo de intervenção na matéria, a existência da teoria só fazendo sentido em razão de sua reverberação nas intervenções práticas. ${ }^{120}$

Isso posto, o que de fato culmina na restauração e, portanto, na preservação do patrimônio cultural, são as intervenções de restauro, pois as definições teóricas, se não aplicadas, não têm valor por si só. Da mesma forma e vislumbrando a superação da dicotomia entre teoria e prática, as questões envolvendo a cor na 
121. Cf. Kühl (2004).

122. Cf. Kuhn, op. cit. preservação do patrimônio edificado só podem ser exploradas a fundo se os aspectos tecnológicos e materiais da arquitetura forem vinculados à interpretação cultural contemporânea. Ou seja, é necessário discutir, do ponto de vista históricocrítico, as intervenções de restauro cromático em sua essência e não apenas a partir das possibilidades técnicas disponíveis. É preciso, portanto, um amadurecimento teórico e crítico voltado a construir uma práxis da conservação, abrangendo a cor das superfícies arquitetônicas enquanto decisão projetual de ampla importância.

Nesse sentido, considerando a necessidade de vínculo entre teoria e prática do restauro e tendo em vista o panorama brasileiro, as reflexões deste artigo se referem à constatação da existência de três paradigmas: o valor de novidade, uma tendência cromática como o uso do amarelo na arquitetura historicista e o turismo cultural. Em conjunto, eles constituem a fundamentação implícita por trás das cores do patrimônio edificado na contemporaneidade. Nesse âmbito, os questionamentos que motivaram a reflexão iniciaram-se com a constatação da incoerência entre o discurso e a prática em esfera nacional, pois, no âmbito do restauro crítico, se cada caso deve ser analisado a partir do seu contexto, da sua origem enquanto fato histórico e das possibilidades de dinâmica e continuidades, porque se visualizam decisões cromáticas idênticas em áreas tão distintas e distantes dos territórios brasileiros, com soluções tão descoladas da realidade espaço-temporal e tão direcionadas ao apelo imagético e ao consumo cultural?

Diante do exposto, o referencial teórico analisado neste artigo permite discorrer sobre a relação fenomenológica entre o observador e as cores da cidade histórica e destaca que o tratamento das superfícies deve ser encarado no processo de restauração em uma análise histórico-crítica, que compreende muito mais do que apenas uma decisão determinada a partir de critérios técnicos. ${ }^{121}$ Nesse sentido, para avançarmos é necessário que primeiramente se reconheça os processos dominantes hoje e as disputas envolvidas no patrimônio cultural brasileiro, entendendo que nas últimas décadas as intervenções cromáticas nas superfícies arquitetônicas dos bens culturais estão sendo realizadas a partir da influência dos paradigmas identificados, e não a partir da análise particular de cada caso.

Assim como para preservar é necessário conhecer o objeto da preservação, para pensar em novas ferramentas e em um plano cromático de conservação é preciso analisar, argumentar e dialogar extensivamente sobre as intervenções cromáticas contemporâneas. É preciso lançar mão de um discurso que preconiza a particularidade de cada caso e perceber que há uma quantidade bastante reduzida de critérios que ordenam como as superfícies dos bens edificados estão sendo pintadas. Portanto, é preciso romper paradigmas, criar novos e construir um conhecimento científico que dê suporte às memórias e identidades coletivas do sujeito contemporâneo. ${ }^{122}$ 


\section{REFERENCIAS}

LIVROS, ARTIGOS E TESES

AGUIAR, José. Cor e cidade histórica: estudos cromáticos e conservação do patrimônio. Lisboa: Faup Publicações, 2002.

BAUDRILLARD, Jean. Simulacros e simulação. Lisboa: Relógio d'Água, 1991.

BEZERRA, Ana Luísa Furquim; NAPPI, Sérgio Castelo Branco. Identificação das cores de fachadas de edificações históricas. Museologia e Patrimônio, Rio de Janeiro, v. 5, n. 1, p. 69-86, 2012.

BRANDI, Cesare. Il restauro: teoria e pratica. Roma: Riuniti, 2009.

BRANDI, Cesare. Teoria da restauração. Cotia: Ateliê, 2008.

CARBONARA, Giovanni. Avvicinamento al restauro: teoria, storia, monumenti. Napoli: Liguori, 1997.

CARBONARA, Giovanni. Brandi e a restauração arquitetônica hoje. Desígnio, São Paulo, n. 6, p. $3547,2006$.

CARBONARA, Giovanni. Il tema del colore in architettura con una riflessione sul caso del Quartiere Coppedé in Roma. Recupero e Conservazione Magazine, Arona, v. 158, p. 10-19, 2020.

CARBONARA, Giovanni. Trattato di restauro architettonico. Torino: Utet, 2004. v. 1.

CARSALADE, Flavio de Lemos. A pedra e o tempo: arquitetura como patrimônio cultural. Belo Horizonte: UFMG, 2014.

CHAUI, Marilena. Convite à filosofia. São Paulo: Ática, 1998.

CHOAY, Françoise. A alegoria do patrimônio. São Paulo: Estação Liberdade, 2001.

COLQUHOUN, Alan. Modernidade e tradição clássica: ensaios sobre arquitetura. São Paulo: Cosac \& Naify, 2004.

DEBORD, Guy. A sociedade do espetáculo. Rio de Janeiro: Contraponto, 2007.

JEUDY, Henri-Pierre. Espelho das cidades. Rio de Janeiro: Casa da Palavra, 2005. 
KÜHL, Beatriz Mugayar. História e ética na conservação e na restauração de monumentos históricos. Revista do IEEE América Latina, São Paulo, v. 1, n. 1, p. 1-11, 2005.

KÜHL, Beatriz Mugayar. O tratamento das superfícies arquitetônicas como problema teórico da restauração. Anais do Museu Paulista, São Paulo, v. 12, p. 309-330, 2004.

KUHN, Thomas Samuel. A estrutura das revoluções científicas. São Paulo: Perspectiva, 1998.

LANCASTER, Michael. Colourscape. Londres: Academy, 1996.

LENCLOS, Jean-Philippe; LENCLOS, Dominique. Colors of the World. The Geography of Color. London: W. W. Norton \& Company, 2004.

LIRA, Flaviana Barreto. Patrimônio cultural e autenticidade: montagem de um sistema de indicadores para o monitoramento. 2009. Tese (Doutorado em Desenvolvimento Urbano) Universidade Federal de Pernambuco, Recife, 2009.

LYNCH, Kevin. A imagem da cidade. 2. ed. São Paulo: Martins Fontes, 2010.

MACHADO, Erika Pereira. A cobertura do Theatro Municipal do Rio de Janeiro: restauração ou reconstrução? 2012. Dissertação (Mestrado em Preservação do Patrimônio Cultural) Instituto do Patrimônio Histórico e Artístico Nacional, Rio de Janeiro, 2012.

MAGAR MEURS, Valerie; SCHNEIDER GLANDZ, Renata (orgs.). Construir teoría. Ciudad de México: Instituto Nacional de Antropología e Historia, 2018.

MONTANER, Josep Maria. Depois do movimento moderno: Arquitetura da segunda metade do século XX. Barcelona: Editora Gustavo Gili, 2011.

MONTANER, Josep Maria; MUXÍ, Zaida. Arquitetura e Política. Barcelona: Gustavo Gili, 2014.

NESBITT, Kate (org.). Uma nova agenda para arquitetura: antologia teórica (1965-1995). São Paulo: Cosac Naify, 2008.

PHILIPPOT, P. La notion de patine et le nettoyage des peintures. Bulletin de l'Institut Royale du Patrimoine Historique, Bruxelles, v. 9, p. 138-143, 1966.

RIEGL, Aloïs. O culto moderno dos monumentos: a sua essência e a sua origem. Goiânia: Editora da UCG, 2006.

ROCHA-PEIXOTO, Gustavo. A estratégia da aranha: ou: da possibilidade de um ensino metahistórico em arquitetura. Rio de Janeiro: Riobooks, 2013. 
ROSADA, Mateus; BORTOLUCCI, Maria Angela Pereira. Os dilemas do restauro da pintura eclética nas igrejas barrocas paulistas. In: CONGRESSO INTERNACIONAL DE REABILITAÇÃO DO PATRIMÔNIO ARQUITETÔNICO E EDIFICADO, 12., 2014, Bauru. Anais [...]. Bauru: Faac, 2014. p. 365-373.

SANT'ANNA, Marcia. A cidade-atração: a norma de preservação de áreas centrais no Brasil dos anos 1990. Salvador: Edufba, 2017.

TIRELLO, Regina. Restaurar não é pintar os edifícios de amarelo. Questões sobre técnicas construtivas tradicionais. In: FONTES, Maria Solange Gurgel de Castro; CONSTANTINO, Norma Regina Truppel; BITTENCOURT, Luiz Cláudio (orgs.). Arquitetura e urbanismo: novos desafios para o século XXI. Bauru: Editora Unesp, 2009. p. 21-35.

VITIELLO, Maria. Identità cromatica e paesaggio. In: ROSSI, Maurizio; SINISCALCO, Andrea (orgs.). Colore e colorimetria: contributi multidisciplinari. Santarcangelo di Romagna: Maggioli, 2012. v. VIII/A, p. 215-221.

VITIELLO, Maria. Il testo e il contesto: per una scrittura narrativa della facies urbana attraverso le superfici e le cromie. In: ROSSI, Maurizio (org.). Colore e colorimetria: contributi multidisciplinari. Santarcangelo di Romagna: Maggioli, 2011. v. VII/A, p. 604-610.

YAÑES, Celia Martinez. Carta Internacional de Turismo Cultural do Icomos de 1999: primeira aproximação para sua revisão e atualização. Revista do Patrimônio Histórico e Artístico Nacional, Brasília, DF, n. 39, p. 71-90, 2019.

ZONNO, Fabiola do Valle. Lugares complexos: poéticas da complexidade: entre arquitetura, arte e paisagem. Rio de Janeiro: FGV, 2014.

SITE

DALLA NEGRA, Ricardo. Forma formante: il progetto di restauro come processo critico. Architetti, [S. l.], 21 abr. 2015. Disponível em: <https://bit.ly/3zrQkmK>. Acesso em: 16 nov. 2020.

Artigo apresentado em: 25/11/2020. Aprovado em: 12/05/2021. (cc) BY 


\section{ERRATA}

\section{Anais do Museu Paulista: História e Cultura Material}

https://doi.org/10.1590/1982-02672022v30e9

No artigo "Da cor à imagem urbana: paradigmas contemporâneos nas cores do patrimônio cultural brasileiro", com número DOl <https://doi. org/10.1590/1982-02672021v29e55>, publicado no periódico Anais do Museu Paulista: História e Cultura Material, vol. 29, 2021 , p. 1-45

\section{Na página 1}

Onde se lia:

ROSINA MARTINS TREVISAN RIBEIRO 3

https://orcid.org/0000-0001-5578-7419

Universidade Federal do Rio de Janeiro / Rio de Janeiro, RJ, Brasil

Leia-se:

ROSINA TREVISAN MARTINS RIBEIRO ${ }^{3}$

https://orcid.org/0000-000 1-5578-7419

Universidade Federal do Rio de Janeiro / Rio de Janeiro, RJ, Brasil

\section{(c) BY}

All the contents of this journal, except where otherwise noted, is licensed under a Creative Commons Attribution License 